\title{
Test Plan, The Czechowice Oil Refinery Bioremediation Demonstration of a Process Waste Lagoon
}

by

D. J. Altman

Westinghouse Savannah River Company

Savannah River Site

Aiken, South Carolina 29808

T. C. Hazen

A. J. Tien

A. Worsztynowicz

Institute for Ecologv of Industrial Areas

Poland

K. Ulfia

Institute for Ecology of Industrial Areas

Poland

DOE Contract No. DE-AC09-89SR18035

This paper was prepared in connection with work done under the above contract number with the U.S.

Department of Energy. By acceptance of this paper, the publisher and/or recipient acknowledges the U. S. Government's right to retain a nonexclusive, royalty-free license in and to any copyright covering this paper, along with the right to reproduce and to authorize others to reproduce all or part of the copyrighted paper.

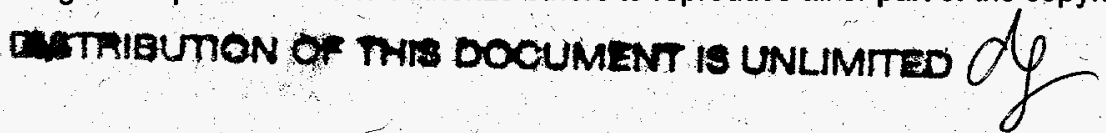




\section{TEST PLAN}

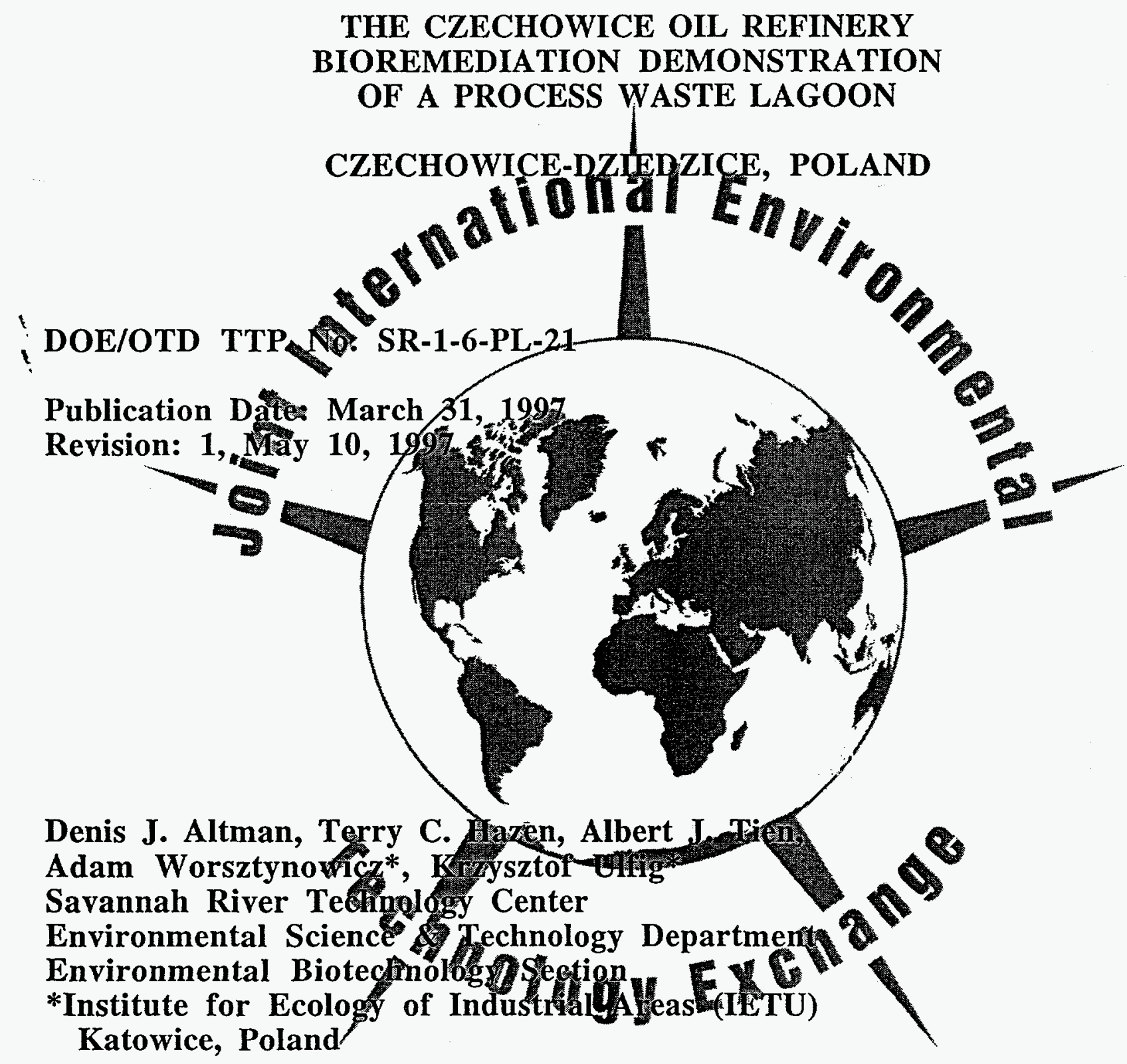

WESTINGHOUSE SAVANNAH RIVER COMPANY SAVANNAH RIVER SITE Aiken, South Carolina 29808 


\section{DISCLAIMER}

This report was prepared as an account of work sponsored by an agency of the United States Government. Neither the United States Government nor any agency thereof, nor any of their employees, makes any warranty, express or implied, or assumes any legal liability or responsibility for the accuracy, completeness, or usefulness of any information, apparatus, product, or process disclosed, or represents that its use would not infringe privately owned rights. Reference herein to any specific commercial product, process, or service by trade name, trademark, manufacturer, or otherwise does not necessarily constitute or imply its endorsement, recommendation, or favoring by the United States Government or any agency thereof. The views and opinions of authors expressed herein do not necessarily state or reflect those of the United States Government or any agency thereof.

This report has been reproduced directly from the best available copy.

Available to DOE and DOE contractors from the Office of Scientific and Technical Information, P.O. Box 62, Oak Ridge, TN 37831; prices available from (615) 576-8401.

Available to the public from the National Technical Information Service, U.S. Department of Commerce; 5285 Port Royal Road, Springfield, VA 22161.

\section{Acknowledgments}

The information contained in this Test Plan was developed during the course of work for the Westinghouse Savannah River Company under Contact No. DE-AC09-89R180035 with the U.S. Department of Energy. In addition, the authors would like to thank the following organizations and personnel for having made significant contributions to the success of this demonstration: The Polish Institute for Ecology of Industrial Areas, Bioremediation Demonstration Team; M. M. Franck, C. B. Fliermans and C. J. Berry from the Savannah River Technology Center, Environmental Biotechnology Section; Hydrolab Corporation for their generous contribution of equipment. Florida State University, Risk Assessment Team; Ames Laboratory, ESC Team; The Czechowice Oil Refinery and their engineering staff; and Mr. Kenneth $\mathrm{H}$. Lombard (who retired from SRTC before field operations began) for his initial efforts in starting this project, preparing the first draft of this test plan and outstanding support of the Polish initiative. 


\section{DISCLAIMER}

Portions of this document may be illegible electronic image products. Images are produced from the best available original document. 
Czechowice Oil Refinery

Bioremediation Demonstration

Test Plan
WSRC-RP-97-214

Revision: 1

May 10, 1997

\section{TEST PLAN SUMMARY}

2. INTRODUCTION

2.1 Historical Background

2.2 Technical Need

2.3 Technology Description

2.4 Benefits

2.5 Alternatives

2.6 Site Description and Area Maps

2.6.1 Area Hydrogeology

2.6.2 Contaminants of Concern

3. TEST PLAN

3.1 Criteria for Success

3.2 Biopile Description

3.2.1 Biopile Design and Construction

3.2.2 System Performance

3.2.3 Cost Analysis

3.3 Process Monitoring

3.3.1 Monitoring Equipment

\section{SAMPLING AND ANALYSIS}

4.1 Soil Sampling Protocol

4.2 Soil Gas Sampling Protocols

4.3 Leachate Sampling Protocols

4.4 Analytical Procedures

4.5 Microbiological Procedures

4.5.1 4, 6 Diamindino 2 phenylindole (DAPI)

4.5.2 Calcofluor White (CFW) - optional

4.5.3 Naphthalene and Crude Oil Enrichment 
Czechowice Oil Refinery

Bioremediation Demonstration

Test Plan

5. HEALTH AND SAFETY

5.1 Other Safety Information.

5.2 Quality Assurance/Quality Control

5.3 Security

6. PATENTS

7. REFERENCES

\section{APPENDICES}

Appendix A List of Acronyms and Abbreviations

Appendix B Biopile Design

Appendix C List of Materials and Equipment

Appendix D Column Study

Appendix E Sample and Monitoring Plan

Appendix F Mobilization Plan

Appendix G Start-Up and Operation Plan

Appendix H Health And Safety Plan
WSRC-RP-97-214

Revision: 1

May 10, 1997 
Czechowice Oil Refinery

Bioremediation Demonstration

Test Plan
WSRC-RP-97-214

Revision: 1

May 10, 1997

\section{TEST PLAN SUMMARY}

The remediation strategies that will be applied at the Czechowice Oil Refinery waste lagoon in Czechowice, Poland are designed, managed and implemented under the direction of The Institute for Ecology of Industrial Areas (IETU), the Westinghouse Savannah River Company (WSRC) for the United States Department of Energy (DOE), Ames Laboratory and Florida State University, Florida State University has the overall lead for the DOE EM-50 Polish Initiative Program. This collaboration between IETU, DOE and its partners, will provide the basis for international technology transfer of new and innovative remediation technologies that can be applied in Poland and the Eastern European Region as well.

The Czechowice Oil Refinery Project will bring together several proven techniques and remediation tools used by WSRC to remove and/or destroy contaminants, via biostimulation of indigenous microbes found in the environment. The strategies employed will include bioremediation, using the natural cleansing capacity of the environment to degrade the hydrocarbon pollutants. A risk based approach will guide the final selection and

remedial design. This approach provides a plan that will take into account the intended future use of the site as

I a green zone between the refinery and the local population, and emphasizes the natural cleansing methods whenever possible. More aggressive techniques could be taken for sites that are to be developed for future uses that would involve higher potential exposure risks to the general public.

A treatability study of the material to be remediated will determine the physical and chemical parameters necessary to maintain and stimulate an active microbial community that can sustain a high biodegradation rate of the contaminants. The treatability study, along with the characterization data will provide the information necessary to design and deploy a bioremediation system capable of producing the stimulus necessary to maintain the biological activity needed to degrade the contaminants to less toxic levels.

The overall objective of the bioremediation project is to provide a cost effective bioremediation demonstration of petroleum contaminated soil at the Czechowice Oil Refinery. Additional objectives include training of IETU personnel, and transfer of this technology by example to IETU, Poland, and the Risk Abatement Center for Central and Eastern Europe (RACE). The goal of the remediation is to reduce the risk of PAH compounds in soil and provide a green zone (grassy area) adjacent to the site boundary. Initial project discussions with the Czechowice Oil Refinery resulted in IETU helping the refinery find an immediate cost effective solution for the dense organic sludge in the lagoons. They found that when mixed with other waste materials, the sludge could be sold as a fuel source to local cement kilns. Thus the waste was incinerated and provided a revenue stream for the refinery to cleanup the lagoon. This allowed the bioremediation project to focus on remediation of contaminated soil that was unusable as fuel, less recalcitrant and easier to handle and remediate. The ESC and Risk Based Assessment identified 19 compounds at the refinery that represented significant risk and would require remediation. These compounds consisted of metals, PAH's, and BTEX. The contaminated soil to be remediated in the bioremediation demonstration contains only PAH (BTEX and metals are not significantly above background concentrations). The final biopile design consists of 1 ) dewatering and clearing lagoon A to clean clay, 2) adding a $20 \mathrm{~cm}$ layer of dolomite with pipes for drainage, leachate collection, air injection, and $\mathrm{pH}$ adjustment, 3) adding a $1.1 \mathrm{~m}$ layer of contaminated soil mixed with wood chips to improve permeability, and 4) completing the surface with $20 \mathrm{~cm}$ of top soil planted with grass. This design will allow the retaining walls of the lagoon to be reduced on the property boundary and produce an immediate green zone while the remediation is taking place. The $2200 \mathrm{~m}^{2}$ treatment area will be divided into approximately $1260 \mathrm{~m}^{2}$ of passive aeration using Baro-ball ${ }^{\mathrm{TM}} \mathrm{s}$ and approximately $940 \mathrm{~m}^{2}$ of active aeration via leachate collection system, air injection. Use of both passive and active aeration methods will allow an accurate assessment of cost vs. efficiency, and the most appropriate design for future lagoon remediation at the refinery. The proposed design should allow for rapid remediation of all types of oil contaminated soil and has also been shown to be applicable to landfill remediation and various other types of 
Czechowice Oil Refinery

Bioremediation Demonstration

Test Plan
WSRC-RP-97-214

Revision: 1

May 10, 1997

shallow waste sites. This demonstration should provide maximum flexibility for application to other sites in the Katowice area, Poland and central/eastern Europe.

\section{INTRODUCTION}

This test plan has been prepared as the guidance document for the design, construction, start-up, operation and test phases of a bioremediation demonstration to be performed at the Czechowice Oil Refinery S.A., in Czechowice-Dziedzice, Poland. Bioremediation is generally attempted by employing biostimulation, a process in which the conditions for microbial growth are optimized by supplying adequate amounts of electron acceptor(s), water, nutrients, in the form of nitrogen, phosphorus and trace elements, to the contaminated material. Because biodegradation rates for petroleum hydrocarbons are fastest under aerobic conditions, maintaining adequate oxygen levels and moisture control are two of the main objectives associated with this project.

The material selected for the technology demonstration contains petroleum sludges, soils contaminated with crude and processed oil and other petroleum by-products and process waste from the refining of crude oil.

The predominant contaminants of concern (COCs) are polycyclic aromatic hydrocarbons (PAHs) including benzo(a)pyrene, a known carcinogen. Also benzene, toluene, ethylbenzene and xylene known as BTEX and very recalcitrant high molecular weight molecules, the remnants and residue from tank bottoms of acid refining of crude oil. Although the high molecular weight molecules represent a portion of the total petroleum hydrocarbons (TPH) present in the waste material, it is of less concern to human health and the environment from a risk assessment stand point, due to their highly insoluble state and lack of mobility within a soil matrix. The bioremediation processes will however, reduce even the highly recalcitrant substances found in the waste material over time. The contaminated material presents several unique challenges to the remediation effort. The refinery and its associated lagoons are over one hundred years old, creating highly weathered conditions and material that will require special handling and preparation for the remediation process to be effective. The integrated bioremediation system (biopile), as designed, will provide the necessary stimulation needed to support the biological processes required to break down the recalcitrant hydrocarbon complexes to a more innocuous and stable material.

Treatability studies were performed to assist in the operation of the biopile and provide preliminary data for modeling purposes.

Wood chips (weathered) were selected as a bulking agent for the biopile because they provide the necessary porosity increase while utilizing an inexpensive waste product from a local lumber mill which otherwise would have to be disposed of. [Wood chips are normally sold as feed stock for pressed wood manufacturing. However, weathered (i.e. old and dirty) chips are not usable and must be disposed of separately.]

Dolomite was selected over other materials e.g., gravel, as the leachate collection layer based on several factors including its ease of handling, relative low cost and availability, $\mathrm{pH}$ amelioration, and a direct and inexpensive transportation route via train from the quarry to the refinery. Dolomite is also available in a variety of screen sizes which will be incorporated into the process design to ensure effective air distribution throughout the system.

The final site use, proposed by the refinery, for the lagoons is a "green zone" to serve as a buffer and visual barrier between the refinery and the city of Czechowice-Dziedzice. The green zone will have limited access by trained refinery and IETU personnel for scientific and research purposes and for continued monitoring of the biopile processes. The area is not intended for recreational use by the general population or the refinery staff. No other regularly scheduled activities associated with the operations of the facility are planned for the site. The removal of the lagoon and the creation of the green zone has great public relations significance and greatly reduces the overall risk of the refinery to the city. 
Czechowice Oil Refinery

Bioremediation Demonstration

Test Plan
WSRC-RP-97-214

Revision: 1

May 10, 1997

\section{$2.1 \quad$ Historical Background}

For more than one hundred years the Czechowice Oil Refinery, formerly the Vacuum Oil Company, owned by the Standard Oil Company of New York, a United States based company, has been producing petroleum products for industrial and commercial applications. Many of the refinery's products are specialty items such as semi-synthetic motor oils, hydraulic oils, high temperature lubricants and waxes. The history of the refinery dates back to 1896 where the refinery processed approximately 35,000 metric tons of paraffinic crude oil a year in the production of vacuum oil. Over the next several decades the refinery's capacity steadily increased with production exceeding 500,000 metric tons per year. During the early 1930 s, the addition of several new product lines and processes transformed the refinery into the largest petroleum processing facility in Poland. With the onset of World War II, the refinery became a military target of the Allied Forces. Due to its high production and strategic location, the Allies bombed the facility in August of 1943. While under German occupation during the war, the Germans rebuilt only part of the refinery, the major restoration was completed by the Poles shortly after the end of World War II and full scale production resumed in February, 1946 (Czechowice Oil Refinery, 1995).

Today, with the end of the cold war and more than 1,300 employees and production exceeding millions of tons per year, in a variety of product lines, the Czechowice Oil Refinery faces many new challenges. The move to a market driven economy and privatization of many State (government) owned industries brings with it new responsibilities, not only in fiscal and business management but also environmental stewardship and ownership. Many years of a production oriented philosophy have created environmental conditions which now present a potential risk to human health and the environment. The disposal practices for process wastes generated by the refining of crude oil have created conditions that are unacceptable under today's environmental standards. The use of unlined lagoons for process waste disposal was the industry norm for many years, not only in Poland but the United States as well. As late as the 1980s some process waste lagoons were still in use in the United States. In Poland the practice still exists.

The Czechowice Oil Refinery, while still following traditional disposal practices, have undertaken new and bold initiatives to begin the environmental restoration of the refinery. In collaboration with the Institute for Ecology of Industrial Areas (IETU), located in Katowice, Poland and the United States Department of Energy (DOE), a program for the demonstration of U.S. based technologies has been initiated with the Czechowice Oil Refinery as the industrial partner. This partnership not only includes the use of the refinery as the demonstration site, but also shared responsibilities in fiscal, construction and engineering management of the project(s).

The primary objectives for the program are to advance Research and Development of EM technologies for use at DOE facilities in the United States and transfer of proven technologies and expertise to Poland. U.S. and foreign cleanup efforts should be accelerated by performing advanced remediation activities on Upper Silesien test sites which have similar contamination problems as those at U.S. sites. The program will serve to address mutual objectives of both Poland and the U.S. related to environmental management. Included among these objectives are the demonstration and international transfer of U.S. environmental technologies, as well as topics related to these issues i.e., risk based management, technology transfer, communications and other forms of information dissemination (FSU, 1995). 


\subsection{Technical Need}

In 1991, 750 million tons of industrial wastes were deposited in the Upper Silesian Region of Poland, mostly in the Katowice Province. Annually, the industry of Katowice Province generates 60-70 million tons of waste. The Upper Silesian Region while rich in natural resources and densely populated, is considered to have very poor quality surface waters (the major source of potable water). Most rivers and streams in the region have very low flow rates on the order of only a few $\mathrm{m}^{3} / \mathrm{s}$. As much as $70 \%$ of the volume of these rivers is made up of municipal sewage and industrial waste water. Some $62.6 \%$ of the $1,400 \mathrm{~km}$ of rivers in the region are out-of-class i.e. class 4 (waste water) or lower (IETU 1994). As sources of clean surface water steadily decline in Poland and throughout the world, our reliance on groundwater will undoubtedly increase far into the next century. Therefore, with increasing urgency, ways have been sought to clean-up, i.e. remediate, petroleum and PAH contaminated soil and groundwater (Hazen 1991). The Czechowice Oil Refinery demonstration will provide DOE-EM and the IETU with the opportunity to demonstrate and evaluate innovative, environmentally sound, and cost effective remediation techniques that can be used throughout the industrialized world to address clean-up of petroleum contaminated sites.

The basic concepts of this technology are expected to be applicable to other sites in the DOE complex having

similar problems, especially low $\mathrm{pH}$; however, the particular process designs will be site specific. The experience gained at the Polish demonstration will provide the basis for designs for other sites in Poland i.e., other refineries and former Soviet military bases.

\subsection{Technology Description}

Bioremediation is a process that mineralizes or transforms hydrocarbons (both xenobiotic and naturally occurring) introduced into the environment to less toxic or innocuous forms (Hazen, 1997). This technique can be applied either in situ or ex situ. There are a variety of bioremediation approaches, including biopiling, bioventing, biosparging and landfarming that can be applied in a large variety of ways. In as much as there are many approaches, so go the problems that accompany the application to a full-scale remedial effort. Such issues include biodegradation enhancement, nutrient and electron acceptor delivery and the integration of combinations of treatment technologies.

The microbial metabolism and fate of BTEX, TPH, PAHs and straight-chain and branched alkanes in the natural environment are areas of intense concern since many of these compounds and their break-down. products display toxic and carcinogenic properties (Hazen, 1991). Many microorganisms including bacteria, fungi, yeast and algae have the enzymatic capacity to completely mineralize petroleum hydrocarbons and utilize the carbon component to generate new biomass. For example, bacteria, under aerobic conditions oxidize PAHs to form dihydrodiols that are utilized in cell production (Atlas, 1984). An example of this bacterial oxidation pathway is the biotransformation of naphthalene to catechol (Fig. 2-1). Naphthalene and other arenes are among the most water soluble and potentially toxic compounds of petroleum and associated products. Indigenous microorganisms in the soil and groundwater can degrade large quantities of petroleum hydrocarbons if they are provided sufficient amounts of water, oxygen, and other limiting nutrients, usually nitrogen and phosphorus (Bartha and Bossert, 1984). Knowing these facts, it is easy to understand why the use of bioremediation as a remedial action is the best method for the treatment of PAHs at the Czechowice Oil Refinery site. Currently, Leaking Underground Storage Tank (LUST) Programs, in many states in the U.S., have selected bioremediation as the clean-up technology of choice. Use of this technology has shown that the 16 PAHs targeted by the USEPA in soil and sludge, in concentrations higher than 5,000 ppm can be reduced by $95 \%$ in twenty weeks or less depending on the ambient conditions (Huis in't Veld et al., 1995). 
Czechowice Oil Refinery

Bioremediation Demonstration

Test Plan
WSRC-RP-97-214

Revision: 1

May 10, 1997

Figure 2-1 Bacterial Oxidation Pathway of Naphthalene to Catechol (Atlas 1984)<smiles>c1ccc2ccccc2c1</smiles>

Naphthalene

in the presence of:

Bacteria $+\mathrm{O}_{2}+$ Dioxygenase

$\downarrow$<smiles>Oc1ccc2ccccc2c1O</smiles>

(+)-cis-1,2-Dihydroxy-1,2-dihydronaphthalene<smiles>CCCC</smiles><smiles>Oc1ccc2ccccc2c1O</smiles>

1,2-Dihydroxynaphthalene<smiles>C1CC1</smiles><smiles>O=C(O)C(=O)Cc1ccccc1O</smiles>

cis-o-Hydroxy benzal pyruvic acid<smiles>CCCC</smiles><smiles>O=Cc1ccccc1O</smiles>

Salicylaldehyde<smiles>CCCC</smiles><smiles>O=C(O)c1ccccc1O</smiles>

Salicylic acid<smiles>C1CC1</smiles><smiles>Oc1ccccc1O</smiles>

Catechol

Meta Pathway

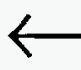

$\downarrow$<smiles>CCCC</smiles>

Ortho Pathway 
Czechowice Oil Refinery

Bioremediation Demonstration

Test Plan
WSRC-RP-97-214

Revision: 1

May 10, 1997

\subsection{Benefits}

Bioremediation technologies are based on biological destruction of the contaminants at the site. Therefore, risks normally associated with handling, transporting, and treating or storing contaminated residuals are lessened, if not avoided. In this sense there is a very significant reduction of risk (Hazen, 1997). Costs for in situ bioremediation of semi-volatile petroleum contamination i.e., polycyclic aromatic hydrocarbons (PAHs) are not well documented since this is an emerging technology. However, current in situ bioremediation technologies for other organics (such as gasoline) are nearly always less expensive than alternative technologies that provide physical destruction of the contaminants.

Bioremediation using techniques like landfarming, biopiling, bioventing, biosparging and nutrient injection will lead to a significant reduction in the time required to complete the remediation because bioremediation provides a pathway for removal (destruction) of the PAHs. Furthermore, the stimulated indigenous microorganisms will gain access to the organic compounds in the soil and water matrices that may be very difficult or impossible to remove by soil vapor extraction or diffusion alone. The enzymes induced in the microorganisms oxidize a host of organic compounds, including toluene, benzene, and PAHs. Many

previous laboratory studies have demonstrated the proof of this principle, thus a "cleaner" end point is reached in less time (Hazen, 1991; Hazen, 1997).

Additionally, IETU will benefit by participating in cooperative projects that advance the R\&D of Polish environmental technologies, demonstrate risk assessment methods and techniques related to soil contamination, which seriously effect the region, and engage in technology transfer, thus laying the foundation for future growth of the remediation and risk assessment fields, including education and skill transfer through cooperation.

\subsection{Alternatives}

A variety of alternative technologies to land disposal or storage in lagoons and basins of untreated petroleum contaminated wastes exist today. They include in situlex situ bioremediation, soil stabilization and solidification, soil vapor extraction, bioventing, excavation and subsequent soil washing and/or chemical treatment and incineration. In order to assure complete remediation, the technology chosen must be able to effectively treat the entire site and produce definable measures of remediation. Additionally, time to remediate, energy costs, required sampling (number of samples and required monitoring period after remediation), etc. must be considered. Several of these technologies have disadvantages that far outweigh the advantage of being used in lieu of ex situ bioremediation (biopiling).

For example, soil stabilization and solidification, although relatively low cost, generate a volume increase in material that requires additional handling and disposal. Because these processes only immobilize the contaminants and do not destroy them, possible limitations on future site use may also exist. Soil vapor extraction and bioventing are viable methods but they can require extensive site characterization and have very site specific applications. These methods also do not provide the level of control or the increased rates of biodegradation that a biopile would. Soil washing (flushing) and chemical treatment can be used as a permanent treatment method but additional waste streams with potentially toxic by-products are generated thus requiring further treatment, disposal and expense. High and low temperature incineration is an effective method to destroy the COCs from this project. However, maintaining the high destruction temperature required to support the removal efficiency of $99.9 \%$ can be costly, requiring the use of large amounts of supplemental fuel to support even the lowest operating parameters. Low temperature (catalytic) incineration is more applicable to petroleum contaminated material remediation but with both high and low temperature applications, permit conditions, contaminant concentrations, material volume, incinerator efficiency, catalyst cost, heating values of the waste, etc. all impact the final cost. 
Czechowice Oil Refinery

Bioremediation Demonstration

Test Plan
WSRC-RP-97-214

Revision: 1

May 10, 1997

Due to the relatively high carbon content of the refinery waste $(\approx 60 \%)$, based on information provided by the refinery engineering staff, the refinery has, through cooperation with the IETU, elected to remove the bulk of the lagoon's material and sell it as an energy source for fuel in a cement kiln. A test burn, at the kiln, of the acidic refinery waste blended with a basic waste from a local chemical plant, was very successful (B. Jagosz, personal communication, 1996). This is an excellent disposal method for the bulk removal of the COCs, that will provide the refinery with an additional source of revenue from what was once considered a waste, and the cement kiln with a relatively low cost, high BTU fuel supply for their production facility. Additionally, the refinery has also developed an extraction process. By steam heating the highly viscous material, found in the lagoon, they recover a usable product for burning in their own steam plant. These forms of energy conservation and usage are highly commendable and should be recognized as innovative in Poland's new market driven economy.

In addition to the lagoon material, the refinery has identified areas of surface contamination (i.e. truck and tank draining locations) which will be utilized as the bed material for the biopile.

! Biopiling: collects of all the contaminated soil; amends it to provide needed nutrients and favorable physical i properties; provides complete containment of the contaminants through the use of a liner and cover material; provides optimal conditions for microbial activity through leachate recirculation and aeration; requires relatively low energy usage; and permits the reuse of the soil once remediation has been completed. In addition, the physicochemical characteristics of the newly identified material; $\mathrm{pH}(7.5 \pm 0.2)$, moisture content $(24.5 \% \pm 10)$, and petroleum content $(14.2 \% \pm 2)$ is superior to the originally selected lagoon material thus making it nearly ideal for a biopiling operation. Therefore biopiling is the only technology that completely degrades the contaminants (without creating a secondary waste stream) and permits the reuse of the (previously) contaminated material without restriction.

\subsection{Site Description and Area Maps}

The Czechowice Oil Refinery is located in the eastern portion of the city of Czechowice-Dziedzice which is located in the Katowice Voivodship in southern Poland (Fig. 2-2; 2-3). The history of the town dates back to the year 1337. Some of the old hamlets like Grabowice, Zbijow or Swierkowice still exist. The Coat-of-Arms of the town of Czechowice-Dziedzice is symbolized by a cog-wheel, representing the towns technical education and mechanical industry. A blue background, which is the color of Silesia, highlights the crest. Yellow ears of corn are drawn on an orange hexagon representing the benzene molecule which is produced in the Silesian Refinery, the main industry in the town and the third largest refinery in Poland (Przedsiebiorstwo Geodezyjno-Kartograficzne 1996). A small city, with a population of approximately 35,000, CzechowiceDziedzice is located approximately 45 kilometers from Katowice and 8 kilometers from Bielsko-Biala (Fig. 24). This region is one of the leading industrial areas of Poland. 
Czechowice Oil Refinery

Bioremediation Demonstration

Test Plan
WSRC-RP-97-214

Revision: 1

May 10, 1997

Figure 2-2 Poland and Katowice/Bielsko-Biala Regional Map

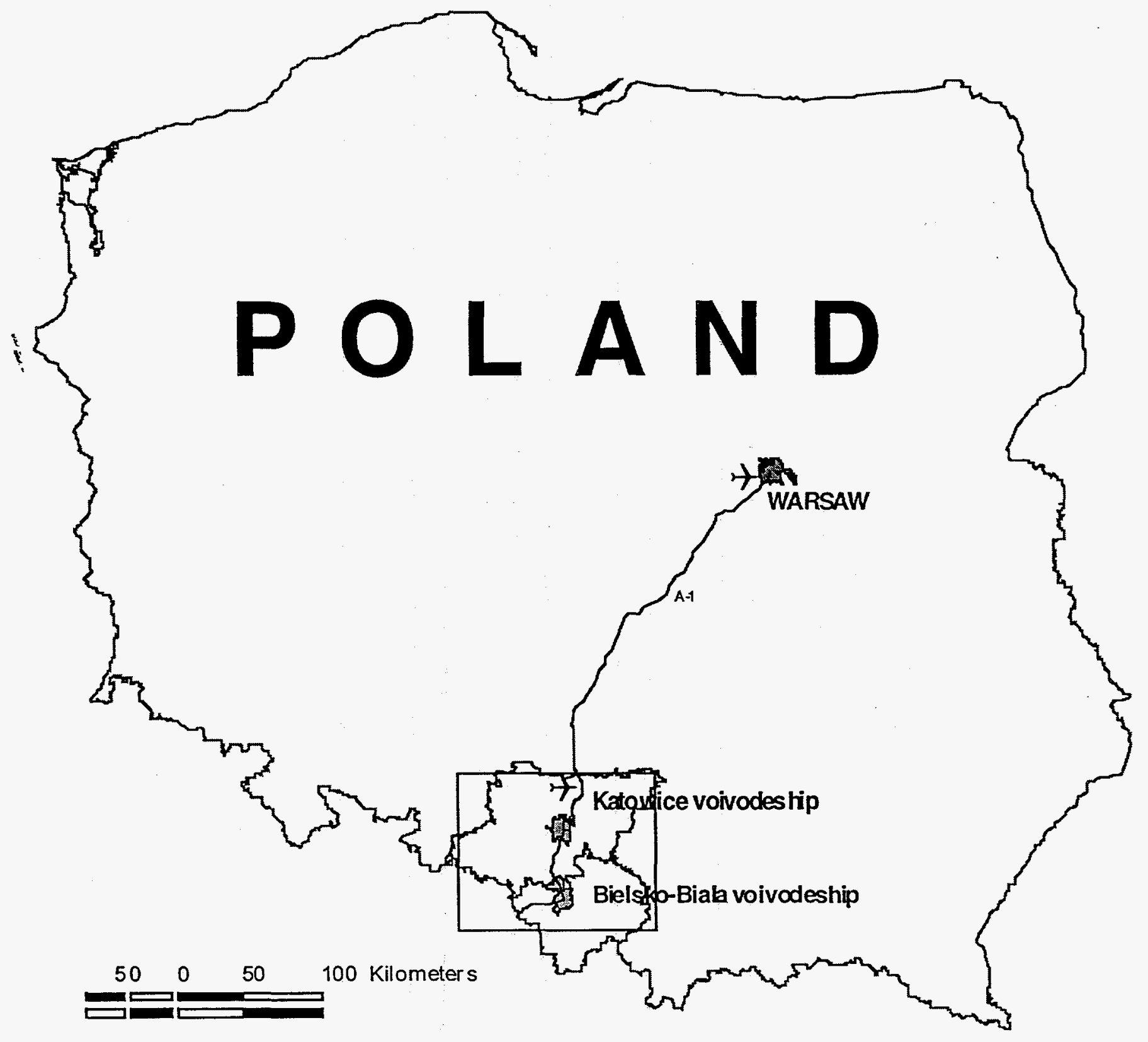


Czechowice Oil Refinery

Bioremediation Demonstration

Test Plan
WSRC-RP-97-214

Revision: 1

May 10, 1997

Figure 2-3 Katowice/Czechowice-Dziedzice Regional Map

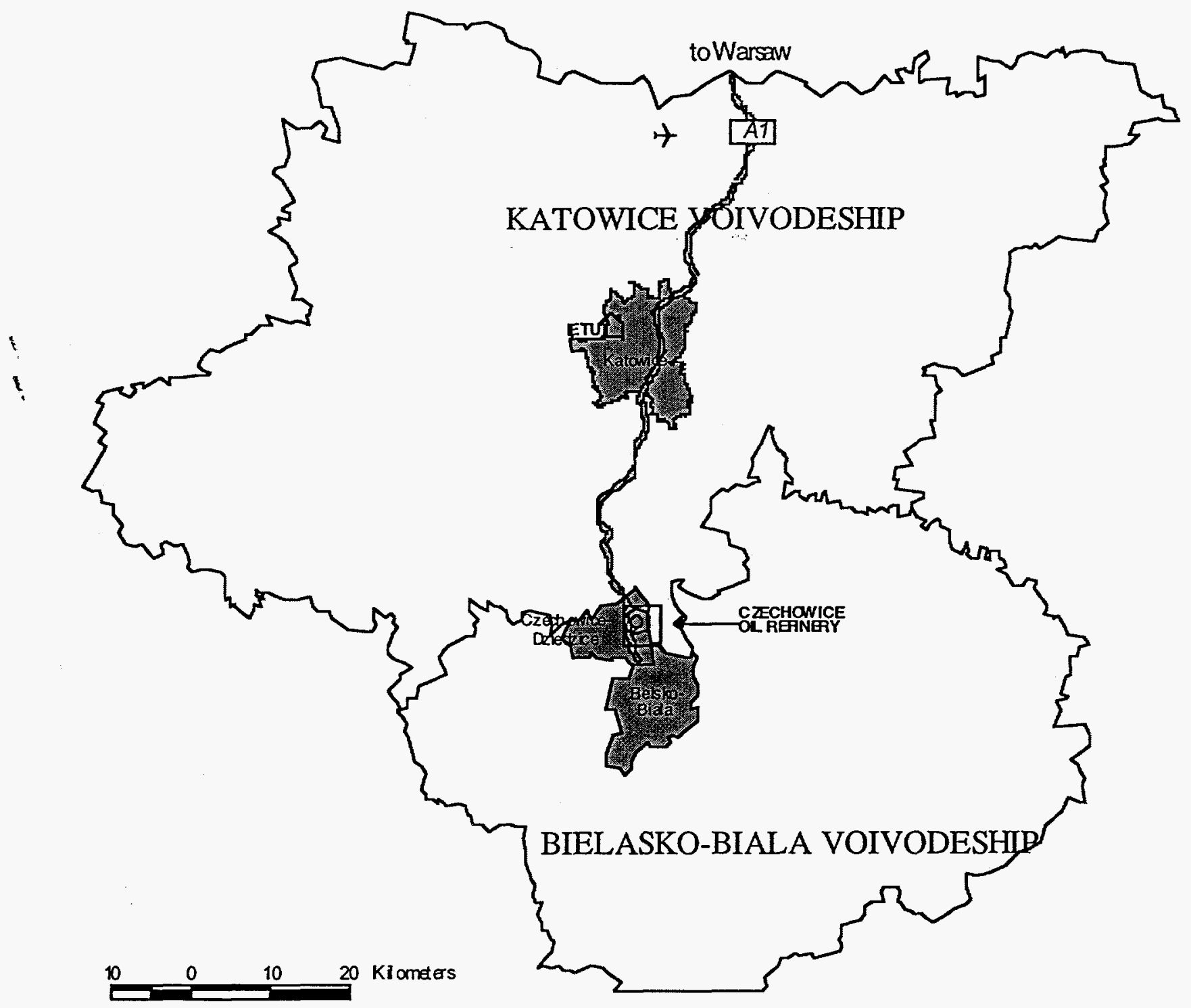


Czechowice Oil Refinery

Bioremediation Demonstration

Test Plan

Figure 2-4 Refinery Location Map
WSRC-RP-97-214

Revision: 1

May 10, 1997

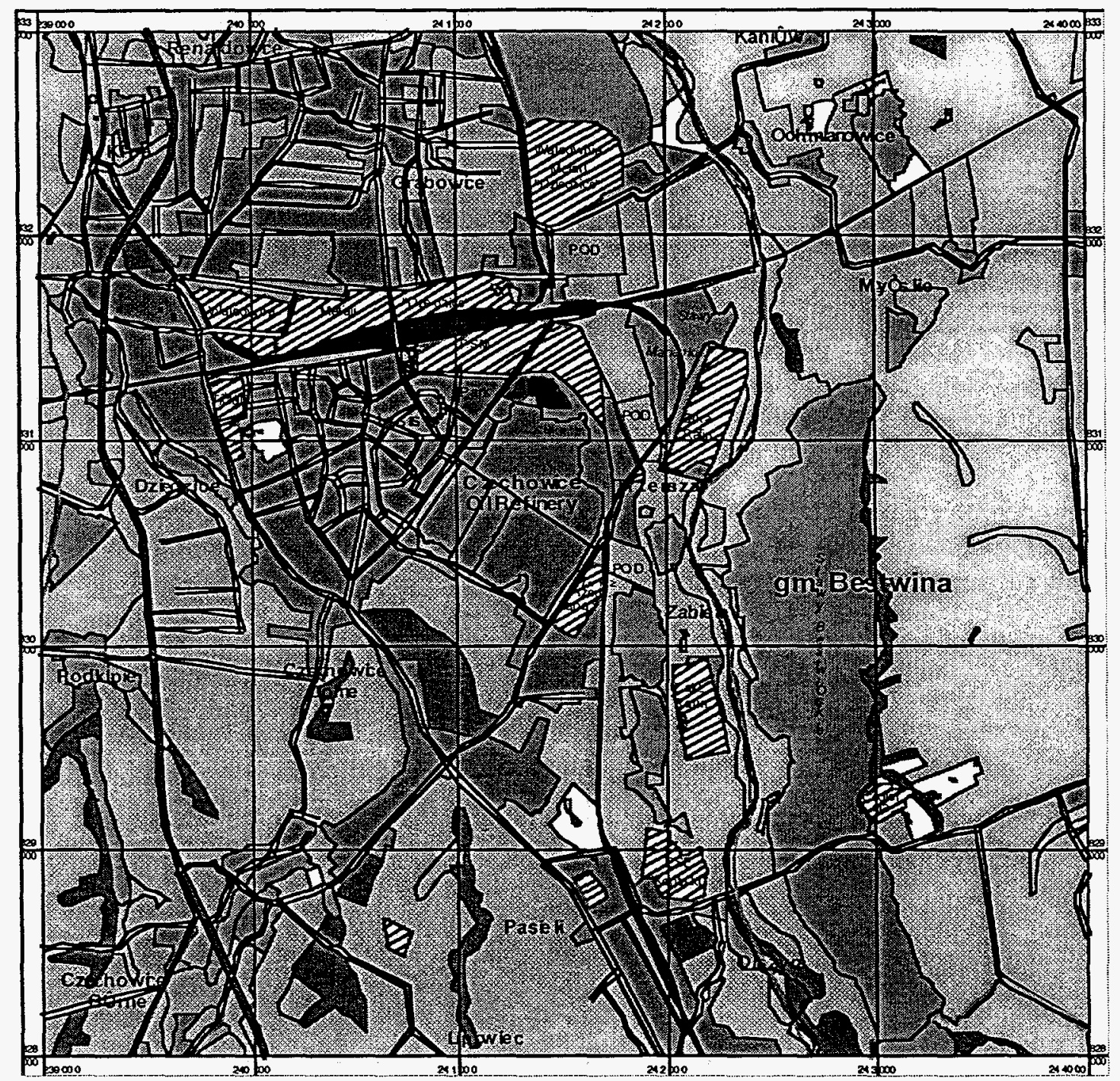




\subsubsection{Area Hydrogeology}

The following section is based on information extracted from the draft Expedited Site Characterization Report of the Czechowice Oil Refinery by Ames Laboratory, Iowa State University, 1996.

Geographically, the refinery is located in the Oswiecim Valley, which is part of the Fore-Carpathian Valleys. The average elevation is 250 meters $(\mathrm{m})$ above mean sea level. The hydrogeology of the area consists of surface water features including the Biala River which is located approximately $500 \mathrm{~m}$ East of the refinery and the Bestwine and Komorow Ponds approximately $1.5 \mathrm{~km}$ East of the river.

Brown and pedosolic soils are present on the surface. In the river valley, soils developed from alluvial deposits are present. Subsurface soils consist of glacial loam, clays, sands and silts. The glacial deposits are 1 to $15 \mathrm{~m}$ in depth. Glacial features occur below alluvial deposits. Gravels with sand and clay are 10 to $30 \mathrm{~m}$ in depth. These Quaternary deposits cover Tertiary age clays. The clays are up to $100 \mathrm{~m}$ in depth and cover a i Carboniferous mudstone series with hard coal beds.

The surface clays and silts have a very low permeability. The estimated hydraulic conductivity of the sand and gravel deposits beneath the refinery is $0.005 \mathrm{~m} / \mathrm{sec}$, based on published information. Hydrogeologic information was collected from wells, which are used for pumping industrial water into the refinery. In 1995 , the water table was measured monthly in nine wells. During the measurement period, the water table was about $12 \mathrm{~m}$ below ground surface (bgs), corresponding to a few meters below the top of the granular aquifer unit.

The thickness of the Quaternary sand and gravel aquifer varies between 8 to $30 \mathrm{~m}$. The direction of the groundwater flow is from SW to NE, based on information from the refinery wells. Surface topographic data suggests a somewhat more easterly direction of flow.

Three piezometers were installed in late winter of 1996 in positions near the targeted NW lagoon (Fig. 2-5). Table 2-1 shows various unit elevations with depths referenced to mean sea level. 
Czechowice Oil Refinery

Bioremediation Demonstration

Test Plan
WSRC-RP-97-214

Revision: 1

May 10, 1997

Figure 2-5 Refinery Lagoons

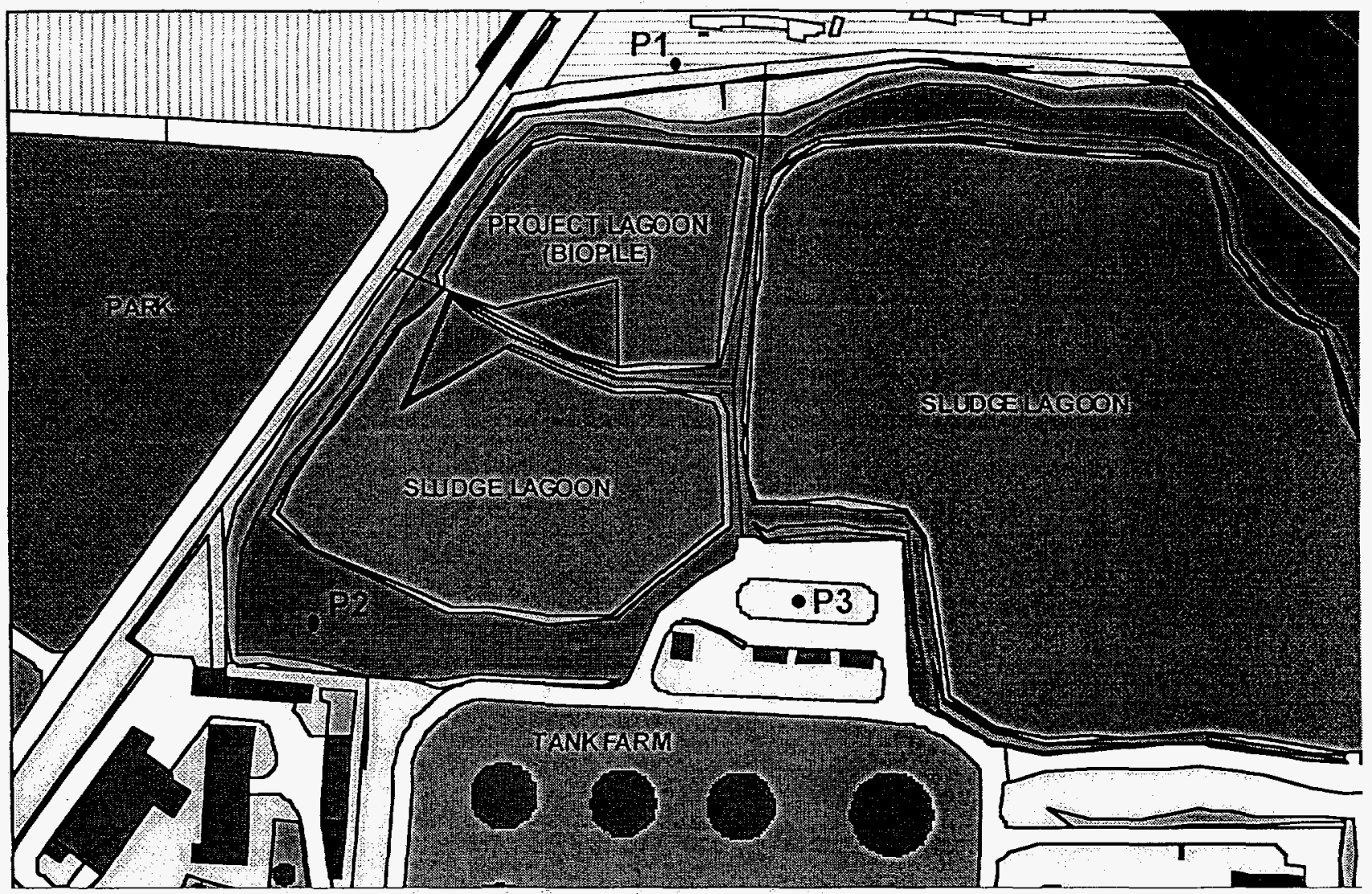


Czechowice Oil Refinery

Bioremediation Demonstration

Test Plan
WSRC-RP-97-214

Revision: 1

May 10, 1997

Table 2-1 Stratigraphic Data on Piezometers (all lengths in meters)

$$
\begin{aligned}
& \text { Surface Elevation to the Bottom of Unit } \\
& \text { Elevation Fill } \quad \text { CL GW CH }
\end{aligned}
$$

\begin{tabular}{llllll} 
P-1 & 261.0 & $261.0^{*}$ & 250.7 & 244.3 & 240.0 \\
P-2 & 263.2 & 260.5 & 250.6 & 244.1 & 238.2 \\
P-3 & 263.5 & 259.8 & 250.4 & 243.7 & 238.5 \\
\hline
\end{tabular}

* Indicates no Fill

$\mathrm{CL}=$ fine grained clay of low to medium plasticity

GW = coarse grained gravel sand mixture ...

$\mathrm{CH}=$ fat clay or very fine high plasticity clay

From Table 2-1 it is clear that the depth above sea level to the top and bottom of aquifer unit (GW) is nearly i the same indicating relatively flat subsurface strata. The aquifer unit is approximately 11 meters below the original ground surface (approximately $13 \mathrm{~m}$ below the top of the lagoon berms), and the aquifer is approximately $6.5 \mathrm{~m}$ thick in the vicinity of the lagoons. 


\subsubsection{Contaminants of Concern}

The Expedited Site Characterization in conjunction with the Site Risk Assessment have identified 19 Contaminants of Concern (COC). The COC and the Polish recommended remediation levels are list below.

\begin{tabular}{|c|c|c|c|c|c|}
\hline \multicolumn{6}{|c|}{ CONTAMINANTS OF CONCERN } \\
\hline & $\begin{array}{l}\mathrm{MCL} \\
(\mathrm{MU})^{1}\end{array}$ & $\begin{array}{l}\mathrm{MCL} \\
\text { (Ind) }\end{array}$ & ESC Mean & ESC High & Biopile \\
\hline \multicolumn{6}{|c|}{ BTEX } \\
\hline Benzene & $\overline{0.2}$ & 100 & 0.12 & 0.90 & 27.4 \\
\hline Ethylbenzene & 1.0 & 200 & 0.04 & 0.28 & 3.3 \\
\hline Toluene & 1.0 & 200 & 0.38 & 2.97 & 14.6 \\
\hline Xylenes & 1.0 & 100 & 0.11 & 0.70 & 7.3 \\
\hline \multicolumn{6}{|c|}{ Polycyclic Aromatic Hydrocarbons (PAHs) } \\
\hline Fluoranthene & 0.2 & 50 & 19.7 & 164 & 6.543 \\
\hline Benzo(b)fluoranthene & 5 & 50 & 4.25 & 44.0 & 1.8 \\
\hline Benzo(k)fluoranthene & 5 & 50 & 1.21 & 6.96 & 1.30 \\
\hline Benzo(a)pyrene & 5 & 50 & 3.7 & 33.1 & 2.29 \\
\hline Benzo(g,h,i)perylene & 10 & 50 & 1.1 & 8.74 & 0.624 \\
\hline Indeno(1,2,3-cd)pyrene & $\mathrm{NR}^{2}$ & NR & 1.1 & 6.27 & 6.16 \\
\hline \multicolumn{6}{|c|}{ Metals } \\
\hline Lead (Pb) & 100 & 600 & 128 & 459 & 209.8 \\
\hline Copper $(\mathrm{Cu})$ & 50 & 300 & 7 & 190 & 70.2 \\
\hline \begin{tabular}{|l|} 
Arsenic (As) \\
\end{tabular} & 20 & 60 & 6 & 21 & 8.92 \\
\hline \begin{tabular}{|l} 
Mercury (Hg) \\
\end{tabular} & 3 & 30 & 0.3 & 2 & 0.44 \\
\hline \begin{tabular}{|l|} 
Nickel (Ni) \\
\end{tabular} & 50 & 300 & 26 & 73 & 29.96 \\
\hline \begin{tabular}{|l} 
Zinc (Zn) \\
\end{tabular} & 150 & 1000 & 220 & $\overline{819}$ & 521.4 \\
\hline Chromium (Cr) & 50 & 500 & 35 & 73 & 46.96 \\
\hline \begin{tabular}{|l} 
Cadmium (Cd) \\
\end{tabular} & 3 & 15 & 1 & 21 & $\sim 0.365$ \\
\hline \begin{tabular}{|l|} 
Cobalt (Co) \\
\end{tabular} & 30 & 200 & 10 & 29 & 0.86 \\
\hline
\end{tabular}

1 - All values in $\mathrm{mg} / \mathrm{kg}$, Polish Maximum Contaminant Level (MCL) guidelines (Industrial Use, 0-2 M), (Multiple Use, 0.3-15 M)

2 - NR = No Recommendation

(IETU Risk Assessment Report, 1997) 
Czechowice Oil Refinery

Bioremediation Demonstration

Test Plan
WSRC-RP-97-214

Revision: 1

May 10, 1997

\section{TEST PLAN}

\subsection{Criteria for Success}

There are three primary criterion by which the overall success of this demonstration will be evaluated:

1. Demonstrate the application of bioventing/biosparging as a viable cost effective process to remediate contaminated sites to reduce risk to man and environment and resulting in a green zone. The ability of the remediation process to degrade large molecular weight compounds (PAHs) will be evidenced by utilizing state-of-the-art monitoring equipment, analytical techniques and treatability studies to determine the rate and volume reduction in the starting concentrations of the contaminants. Deliverables include; 1) Training for IETU personnel in the use and application of monitoring equipment, 2) Bioremediation demonstration test plan, 3) Functional design criteria for the full-scale bioremediation demonstration, 4) Presentation of the project at Warsaw ' 96 , and 5) writing a final report.

2. Evidence of biological destruction (biodegradation) of petroleum (PAH, TPH and BTEX) from the contaminated material. Since a major advantage of bioremediation is destruction, it is important and significant to demonstrate that biodegradation is occurring. The evidence is expected to come primarily from comparison of the biopile material and soils analysis taken before, during and after the material is subjected to the treatment process (nutrient addition, aeration, $\mathrm{pH}$ adjustment and moisture control) to stimulate biodegradation.

3. Relatively simple and trouble-free operation. A critical assumption for the successful demonstration of the technology is that the system, as designed, will function with little or no down time and provide operating conditions that minimize fugitive air emissions and maximize biodegradation rates. The proposed project has no precedence in Poland and as such represents new technology for the country. However, since several other nations have demonstrated similar technologies, it represents a relative low risk and should have high public acceptance. The simplistic design contributes direct benefits associated with the ease of management and operation. A minimal staff will be required to operate the equipment, again adding to the low risk factor by limiting exposure to operations personnel.

\subsection{Biopile Description}

This bioremediation demonstration project will focus mainly on the clean-up technique known as "biopiling". The biopile process is very similar to active bioventing, where air, as an oxygen source, and other amendments are forced through the vadose zone sediments either by vacuum extraction or by injection to stimulate the microbial oxidation of the hydrocarbons. As the name implies, biopiling is an ex situ process. The contaminated material is excavated and recombined or amended with other materials e.g., nutrients, sand, sawdust, wood chips, compost or other similar bulking agents, as needed, to improve permeability and moisture retention, and then placed in an engineered structure (configuration), to support and stimulate the biological reactions necessary to oxidize the hydrocarbons. Typically, this is a composting process which utilizes forced air via injection or vacuum extraction, moisture control, nutrient addition and environmental monitoring. Using commercially available vacuum pumps, or blowers, leachate pumps, moisture probes, thermocouple temperature probes, and real time soil gas monitoring equipment provides a mature and effective technology base for the operation and monitoring of the biopile. 


\subsubsection{Biopile Design and Construction}

In this project, a biopile will be constructed utilizing contaminated soil amended with wood chip waste. The pile will be constructed in the existing excavated lagoon as seen in DWG. POL-DJA-005; App. A. The empty lagoon bottom will be sloped toward a sump pump which will be connected to the leachate collection piping . A leachate collection system consisting of perforated leachate collection piping will be placed at the bottom of a dolomite base, approximately $1 \mathrm{ft}(30.48 \mathrm{~cm})$ deep. A cell divider (constructed of clay) will placed within the dolomite to create a separate active and passive section of the biopile. This has been done at the request of the refinery to provide a direct comparison of an active and passive system. The conceptual schematic with all potential process flows is presented in Figure 3.1. 
Czechowice Oil Refinery

Bioremediation Demonstration

Test Plan
WSRC-RP-97-214

Revision: 1

May 10, 1997

The sump and its associated pump (DWG. POL-DJA-005; App. A), will recirculate any collected leachate to the top of the biopile. In addition, make-up water from the existing waste water treatment facility at the refinery, will ensure that an adequate supply of moisture is available. The high concentration of bacteria in the make-up water $\left(>10^{8} / \mathrm{ml}\right)$ will also serve as a source of innoculum for the biopile.

As described by the USEPA (EPA/540/R-95/534a), one driving force behind the development of bioventing was the difficulty of delivering oxygen in situ. Many contaminants, especially petroleum hydrocarbons, are biodegradable in the presence of oxygen. Enhanced bioremediation processes use water to carry oxygen or an alternative electron acceptor to the contaminated zone. This process was common, whether the contamination was present in the ground water or in the unsaturated zone. Media for adding oxygen to contaminated areas have included pure-oxygen-sparged water, air-sparged water, hydrogen peroxide, and air. In all cases where water is used, the solubility of oxygen is the limiting factor effecting mass transfer. At standard conditions, a maximum of $8 \mathrm{mg} / \mathrm{L}$ to $10 \mathrm{mg} / \mathrm{L}$ of oxygen can be obtained in water when aerated. The stoichiometric equation 3.2.1 shown below is an example that can be used to calculate the quantity of water that must be delivered to provide sufficient oxygen for biodegradation.

$$
\text { Eq. 3.2.1 } \quad \mathrm{C}_{6} \mathrm{H}_{14}+9.5 \mathrm{O}_{2} \rightarrow 6 \mathrm{CO}_{2}+7 \mathrm{H}_{2} \mathrm{O}
$$

!

An example of the mass of water that must be delivered for hydrocarbon degradation to occur is shown below. Based on Equation 3.2.1, the stoichiometric molar ratio of hydrocarbon to oxygen is 1:9.5 or, to degrade 1 mole of hydrocarbon, 9.5 moles of oxygen must be consumed. On a mass basis:

$$
\frac{1 \text { mole }_{6} \mathrm{H}_{14}}{9.5 \text { moles }_{2}} \times \frac{1 \text { mole O}_{2}}{32 \mathrm{~g} \mathrm{O}_{2}} \times \frac{86 \mathrm{~g} \mathrm{C}_{6} \mathrm{H}_{14}}{1{\text { mole } \mathrm{C}_{6} \mathrm{H}_{14}}_{14}}=\frac{86 \mathrm{~g} \mathrm{C}_{6} \mathrm{H}_{14}}{304 \mathrm{~g} \mathrm{O}_{2}}=\frac{1 \mathrm{~g} \mathrm{C}_{6} \mathrm{H}_{14}}{3.5 \mathrm{~g} \mathrm{O}_{2}}
$$

Given an average concentration of $9 \mathrm{mg} / \mathrm{L}$ of oxygen dissolved in water, the amount of air-saturated water that must be delivered to degrade $1 \mathrm{~g}$ of hydrocarbon is calculated as follows:

$$
\frac{3.5 \mathrm{~g} \mathrm{O}_{2} \text { required }}{\frac{9 \mathrm{mg} \mathrm{O}}{1 \mathrm{~L} \mathrm{H}_{2} \mathrm{O}} \times \frac{1 \mathrm{~g}}{1,000 \mathrm{mg}}}=\frac{390 \mathrm{~L} \mathrm{H}_{2} \mathrm{O}}{1 \mathrm{~g} \mathrm{C}_{6} \mathrm{H}_{14}}
$$

or, to degrade $1 \mathrm{lb}$ :

$$
\frac{390 \mathrm{LH}_{2} \mathrm{O}}{1 \mathrm{~g} \mathrm{C}_{6} \mathrm{H}_{14}} \times \frac{1,000 \mathrm{~g}}{2.2 \mathrm{lb}}=178,600 \mathrm{~L} \mathrm{H}_{2} \mathrm{O} / 1 \mathrm{lb} \mathrm{C} \mathrm{H}_{14}
$$


Czechowice Oil Refinery

Bioremediation Demonstration

Test Plan
WSRC-RP-97-214

Revision: 1

May 10, 1997

\section{Table 3-1 Oxygen Requirements Based on Source}

\author{
Oxygen Form \\ Air-saturated $\mathrm{H}_{2} \mathrm{O}$ \\ Oxygen-saturated $\mathrm{H}_{2} \mathrm{O}$ \\ Hydrogen peroxide \\ Air \\ $\mathrm{NA}=$ not applicable.
}

$\begin{array}{lc}\begin{array}{l}\text { Oxygen } \\ \text { Concentration in } \mathrm{H}_{2} \mathrm{O}\end{array} & \begin{array}{c}\text { Volume to } \\ \text { Degrade } 1 \mathrm{lb}\end{array} \\ & \text { Hydrocarbon } \\ 8 \mathrm{mg} / \mathrm{L} \text { to } 10 \mathrm{mg} / \mathrm{L} & 180,000 \mathrm{~L} \\ 40 \mathrm{mg} / \mathrm{L} \text { to } 50 \mathrm{mg} / \mathrm{L} & 42,000 \mathrm{~L} \\ \mathrm{Up} \text { to } 500 \mathrm{mg} / \mathrm{L} & 6,100 \mathrm{~L} \\ \mathrm{NA}(21 \% \text { vol./vol. in air) } & 4,800 \mathrm{~L}\end{array}$

Based on current findings from the IETU treatability study, and an understanding of the mass transfer limitations of air-saturated water as an oxygen delivery system and the costs and safety concerns associated with pure oxygen generation, air injection was selected for the biopile electron acceptor delivery system. Clearly, the goals established by the risk assessment for the clean-up criteria and the final end use of the site will be met with this process.

Previous field demonstrations at SRS have shown that direct air injection is an acceptable method of delivering oxygen to the subsurface microbiota. Additionally, a recent demonstration at a local municipal landfill (Columbia County, GA), has shown that air can be delivered via the leachate collection piping without adversely impacting the collection of leachate. This dual use of the leachate collection system (Dwgs. POL-DJA-005, POL-DJA-006, and POL-DJA-007 App. A) will also be applied to the construction of the biopile. A regenerative blower has been obtained to provide the necessary air flow for the biopile. The Columbia County Landfill demonstration has shown that air injected into the perforated leachate collection piping is distributed to the entire cell via the leachate drainage layer (i.e. dolomite) (Dwg. POL-DJA-007, App. A).

Approximately 1 meter of amended biopile material will be placed above the leachate collection system. The composition of the mixture will be approximately $80 \%$ to $90 \%$ contaminated material, and $10 \%$ to $20 \%$ wood chips as a bulking agent. A more exact mixing ratio of the contaminant mixture will be provided upon completion of the column study for permeability being conducted by IETU.

Immediately above the amended biopile material a 20 to $30 \mathrm{~cm}$ of cover (i.e. top soil or humus) will be placed. The cover will be planted with grass seed which will provide protection from erosion, support of a green zone and provide a biofilter for any gaseous substances which may reach the surface of the biopile.

Atop of the biopile, a trickle system for water application will be installed to maintain soil moisture between $20-80 \%$ of the biopile's field capacity. The target range is 30-40\%. The water supply will come from the leachate collection sump with make-up water coming from the refinery's waste water treatment system.

\subsubsection{System Performance}

Biodegradation of petroleum hydrocarbons in soil (petroleum land farming) has been used by the oil industry for more than 30 years as an efficient way to destroy oil sludges (Bartha and Bossert, 1984). By applying oil to the soil surface, adding fertilizer ( $P \& N$ ), water, and then tilling to aerate (oxygenate), the soil microbes have been shown to completely degrade large quantities of oil. A demonstration of this technology using waste oil was done at the Savannah River Site near Central Shops in 1980 (Watts and Corey, 1982).

Until recently, the state-of-the-art approach to soil remediation was excavation and disposal at a secure landfill. 
Czechowice Oil Refinery

Bioremediation Demonstration

Test Plan
WSRC-RP-97-214

Revision: 1

May 10, 1997

Changes in liability concerns, increasing costs, and regulatory constraints have decreased the popularity of excavation and disposal as a soil cleanup alternative. Landfill disposal of contaminated soil does not remove the future liability of its generator, who will be held jointly liable with the landfill operator for any future associated contamination. Thus, on site permanent solutions must be sought whenever possible.

At this time, it has been estimated, based on previous work performed by WSRC and others, that the removal of BTEX will be between $90-99.9 \%$ with a reduction in TPH of $65-90 \%$ and PAH removal between $50-75 \%$. Sims (1986) reported 50-100\% reduction of fossil fuels in soil after only 22 days. St. John and Sikes (1988) reported that a prepared bed system, complete with fugitive air emissions control, at a Texas oil field was able to reduce volatile organic carbon by $>99 \%$ after 94 days, with semivolatiles being reduced by more than $89 \%$. In California, Ross et al. (1988) reported that four acres of soil 15 in $(38 \mathrm{~cm})$ deep, contaminated with diesel and waste motor oils were decreased from $2,800 \mathrm{ppm}$ TPH to less than $380 \mathrm{ppm}$ in only four weeks. He also reported that at another site owned by a heavy equipment manufacturer, $7,500 \mathrm{~m}^{3}$ were reduced to $<100 \mathrm{ppm}$. TPH after nine weeks and an additional $9,000 \mathrm{~m}^{3}$ with $180 \mathrm{ppm}$ TPH were reduced to $<10 \mathrm{ppm}$ after only five weeks. Another site in California had $600 \mathrm{~m}^{3}$ reduced from $1000 \mathrm{ppm}$ TPH to $<200 \mathrm{ppm}$ in 35 days. Molnaa and Grubbs (1989) report other sites in California where similar results were obtained, e.g., $2000 \mathrm{~m}^{3}$ with

$2800 \mathrm{ppm}$ TPH were reduced to less than $38 \mathrm{ppm}$ in 74 days, a truck stop where $15,000 \mathrm{~m}^{3}$ were reduced from $3000 \mathrm{ppm}$ TPH to less than $30 \mathrm{ppm}$ TPH in 62 days, and a site contaminated with lubricating oils where

$25,000 \mathrm{~m}^{3}$ were reduced from $4800 \mathrm{ppm}$ down to $125 \mathrm{ppm}$ in 58 days. Based on the initial concentrations (> $200,000 \mathrm{mg} / \mathrm{kg}$ TPH in litter) reported by Ulfig, et al. (1996), the rates of removal should range between 10 to $80 \mathrm{mg} / \mathrm{kg}$ of soil per day for TPH and could exceed $120 \mathrm{mg} / \mathrm{kg}$ of soil per day, based on similar work by Reisinger, et al. (1996). Reisinger experienced a $41 \%$ removal of TPH over the first two quarters (180 days) of biopile operations, based on respiration test data. Seasonal variations and other system parameters will also impact removal rates.

\subsubsection{Cost Analysis}

Cost analysis of this project (demonstration) is highly variable at this time. Based on in-kind contributions by the refinery, IETU and others for the procurement of materials, equipment and labor to support the construction, operations, sampling and analysis necessary to complete the project, costs could range from $\$ 300 \mathrm{k}$ to $\$ 500 \mathrm{k}$ USD. Again, keeping in mind that this project is a demonstration of a variety of technologies. Occasions may arise that will provide a "window of opportunity" for the development of new and unique technological applications that could effect the estimated cost of the project. Not with-standing the existing conditions at the project site, the cost and clean-up of the site could actually be less than first projected.

\subsection{Process Monitoring}

Monitoring of the system (see Table 4-2) will be accomplished in a variety of ways. Soil gas piezometers will be installed in the biopile to monitor carbon dioxide $\left(\mathrm{CO}_{2}\right)$, oxygen $\left(\mathrm{O}_{2}\right)$, methane $\left(\mathrm{CH}_{4}\right)$, volatile organic hydrocarbons (VOCs) and semi-volatile organic hydrocarbons (sVOCs). Water and soil samples will by analyzed for polycyclic aromatic hydrocarbons (PAHs), nutrients, inorganics and microbiological activity. Water quality of the leachate will be tested for $\mathrm{pH}$, dissolved oxygen (DO), specific conductance, temperature and other chemical and physical parameters like BOD and COD. The data gained from the monitoring program will be used to calculate the biodegradation rates for PAH and total petroleum hydrocarbons (TPH). Respiration testing will be conducted to monitor $\mathrm{O}_{2}$ utilization during the remediation and helium tracer tests will be performed to monitor the air flow, distribution and hydraulic conductivity with respect to the permeability of the contaminant mixture within the biopile during air injection. Moisture and temperature will be measured by in situ moisture probes and thermocouples set next to each of the vadose zone piezometers. This information will enable an appraisal to be done on the remediation time necessary to meet the clean-up criteria set by the risk assessment. 


\subsubsection{Monitoring Equipment}

The products and manufacturers used on this project are listed in this document, and are meant as guidance for environmental managers and consulting engineers.

The Brüel \& Kjær (B\&K) Multi-gas Monitor, Type 1302 is a highly accurate, reliable and stable quantitative gas analyzer which is microprocessor controlled. Its measurement principle is based on the photoacoustic infra-red detection method. In effect this means that the B\&K 1302 can be used to measure almost any gas which absorbs infra-red light. The $1302 \mathrm{~s}$ detection threshold is gas-dependent but typically in the $10^{-3} \mathrm{ppm}$ region (Brüel \& Kjær, 1996). In this project the B\&K will serve a dual role. First, the instrument will be used for personnel occupational health and safety monitoring. Initial environmental sampling indicates the presence of benzene, a known human carcinogen. The instrument assigned to this project has been set-up and calibrated for benzene monitoring. The second role the instrument will be used for is process monitoring of soil gases. The B\&K is set-up to selectively measure the concentration of up to 5 component gases and water $\checkmark$ vapor in any air sample. For this project the instrument will monitor benzene, toluene, xylene(s) and naphthalene as well as $\mathrm{CO}_{2}$ and water vapor.

The Landtec GEM-500 Gas Extraction Monitor is a highly reliable gas monitoring unit originally designed for the detection of landfill gases. The Landtec GEM-500 is designed to detect $\mathrm{CH}_{4}, \mathrm{CO}_{2}$ and $\mathrm{O}_{2}$ concentrations in soil gas. Because the biopile is designed to be an aerobic system the GEM-500 will be employed to monitor the production of $\mathrm{CO}_{2}$ and the depletion of $\mathrm{O}_{2}$ and in this case, the lack of the presence of methane indicating aerobic conditions exist in the subsurface of the biopile. The lack of $\mathrm{CH}_{4}$ production and the presence of $\mathrm{CO}_{2}$ indicate the system is providing an adequate $\mathrm{O}_{2}$ supply for the aerobic biological processes to take place. The instrument's detection ranges are $0-100 \%$ for methane, $0-50 \%$ for carbon dioxide and $0-25 \%$ for oxygen with a resolution of 0.1 for all gases.

In a former acid refining process used for the manufacture of motor oil, large quantities of sulfuric acid $\left(\mathrm{H}_{2} \mathrm{SO}_{4}\right)$ were used in the processing operation. The $\mathrm{H}_{2} \mathrm{SO}_{4}$ was disposed of in the waste lagoons creating a potential health hazard when the materials are mixed or disturbed. In order to monitor the airborne concentrations of $\mathrm{H}_{2} \mathrm{SO}_{4}$ during the construction and operation of the biopile system a Single Point Monitor (SPM) manufactured by Zellweger Analytics will be deployed. The SPM combines the Chemcassette ${ }^{\mathrm{TM}}$ Detection System and microprocessor control to achieve optimum detection speed, accuracy, and specificity. It responds quickly to hazardous releases, yet ignores other commonly used chemicals.

Soil moisture will be monitored through the use of multiple gypsum moisture blocks installed throughout the biopile at approximately the same locations as the soil piezometers. The soil moisture blocks consist of two concentric electrodes cast into gypsum blocks. When the blocks are placed within the biopile, the moisture content of the gypsum approaches equilibrium with the moisture content of the biopile material. When the electrodes of the moisture block are connected to a moisture meter, a current is passed between the electrodes and the resulting resistance is measure and converted to a meter display. The meter display can then be transformed to a percent of Available Soil Moisture. The moisture meter is a battery powered hand held device about the size of a scientific calculator. The moisture meter is carried between sample locations, the moisture block leads are connected to the meter, and the moisture measurement is displayed. The moisture blocks and moisture meter (Model KS-D1) utilized in this project were manufactured by Delmhorst Instrument Company, Towaco NJ.

Soil temperature will be monitored using J Type or K Type thermocouples placed within the biopile at approximately the same locations as the piezometers and moisture blocks. Standard Grade Type J thermocouples employ a Iron Constantan (Copper nickel alloy) junction with a temperature range of $-200 \infty \mathrm{C}$ to $760 \propto \mathrm{C}(-328 \infty \mathrm{F}$ to $1400 \infty \mathrm{F})$. Standard Grade Type K thermocouples employ a Chromel (Chromium- 
nickel) Alumel (Aluminum-nickel) junction with a temperature range of $-200 \propto \mathrm{C}$ to $1370 \propto \mathrm{C}(-328 \infty \mathrm{F}$ to $2498 \infty \mathrm{F}$ ). When the junction of the thermocouple is subjected to a temperature, a current is produced which is indicative of the temperature at the junction. Thermocouples are usually supplied with Type $\mathrm{K}$ mini male plugs which are compatible with the thermometer (readout device) and orient the thermocouple leads to the correct polarity. The thermometer is also a battery powered hand held device about the size of a scientific calculator. The thermometer is carried between sample locations, the thermocouple plug is inserted into the thermometer and the temperature of the thermocouple location is displayed within moments. The readout device being used on this project is a Fluke Model $52 \mathrm{~K} / \mathrm{J}$ Thermometer manufactured by the John Fluke Manufacturing Co. Inc., Everett, WA. 
Czechowice Oil Refinery

Bioremediation Demonstration

Test Plan
WSRC-RP-97-214

Revision: 1

May 10, 1997

\section{SAMPLING AND ANALYSIS}

Soils will be collected during the Expedited Site Characterization (ESC), the initial phase of the remediation demonstration and again for post demonstration characterization for analysis of VOCs, microbial counts, physical parameters, and miscellaneous parameters. The amount of soil sampling conducted at a site has a tremendous impact on the cost of the project. Minimizing soil sampling makes a remediation effort much more cost-effective. Since the biopile contaminated soil is being mixed with wood chips, the soil matrix should be much more homogeneous than the native soil, thus random soil sampling of the passive and active zones should provide a reasonable estimate of soil parameter changes during interim sampling intervals. With biopile systems, in situ respiration testing can also indicate when the site is clean and, therefore, when to collect final soil samples.

Periodic soil gas monitoring will be conducted to ensure that the biopile system is well oxygenated. Initially, soil gas will be monitored weekly until the site becomes fully aerated. Once full aeration is achieved, system operation can be optimized. After this initial period, soil gas monitoring normally is conducted bi-monthly for the first year, during the warmest and coldest months, and monthly thereafter. If conducting an in situ

respiration test during different seasons is not possible, then it should be conducted during the same seasons as the initial test. In situ respiration testing should be used as a preliminary indicator for site closure. A good indication that the site is remediated and that final soil sampling can be conducted is an in situ respiration rate in the contaminated area similar to that in the uncontaminated area. In situ respiration testing to determine remediation success is economically significant because soil sampling is not relied upon as the sole indicator of site remediation, thus eliminating the high cost of intermediate soil sampling.

\subsection{Soil Sampling Protocol}

Soils for organic and inorganic analysis will be collected using a hand auger, and placed in a Whirl-Pak bag or other clean container. Samples will be placed in a cooler on ice and managed according to the hold times as seen in Table 4-1. Prior to sample analysis, samples will be weighed to determine the mass of the sample. Core specimens for microbial analysis will be obtained directly from the soil sampler. Cores will be sectioned with sterile spatulas and the outermost layer scraped off using a sterile scoopula. The sample will then be placed in a sterile Whirl-Pak bag and transported to the laboratory on ice for immediate analysis according to this test plan. Laboratory analyses will be performed by personnel at the IETU laboratory. 
-

\begin{tabular}{|c|c|c|c|c|c|c|c|c|c|c|c|c|c|c|c|c|c|c|}
\hline \multirow{2}{*}{$\begin{array}{l}\text { Required } \\
\text { Parameters }\end{array}$} & \multicolumn{4}{|c|}{ Soil } & \multicolumn{5}{|c|}{ Gas } & \multicolumn{4}{|c|}{ Water/Liquild } & \multirow{2}{*}{$\begin{array}{l}\text { Analysis } \\
\text { Type }\end{array}$} & \multirow[b]{2}{*}{ Ret. } & \multirow[t]{2}{*}{ Analyst } & \multirow{2}{*}{$\begin{array}{l}\text { Hold } \\
\text { Time }\end{array}$} & \multirow[t]{2}{*}{ Priority } \\
\hline & Base & $w_{k}$ & $M n$ & Final & Base & Daily & Wk & $\mathrm{Mn}$ & Final & Base & $\mathrm{Wk}_{\mathrm{k}}$ & $\mathrm{Mn}$ & Final & & & & & \\
\hline DAPI & $\checkmark 2$ & & $\checkmark$ & $\checkmark$ & & & & & & $\sqrt{2}$ & & 8 & $\checkmark$ & Micro & & $\mathrm{KU}$ & 3 wks Fixed \& $94^{\circ} \mathrm{C}$ & 2 \\
\hline CFW (optional) & $\checkmark 2$ & & $\checkmark$ & 2 & & & & & & $\checkmark 2$ & & $\checkmark$ & $\checkmark$ & Micro & & $K$ & $24 \mathrm{hr} \cdot 4^{\circ} \mathrm{C}$ & 3 \\
\hline Naphtalene-degraders 7 & $\checkmark 2$ & & $\checkmark$ & 5 & & & & & & $\checkmark 2$ & & $\checkmark$ & $\checkmark$ & Micro & & KU & $8 h r @ 4^{\circ} \mathrm{C}$ & 1 \\
\hline Crude Oll-degraders 7 & $\checkmark 2$ & & $\checkmark$ & 6 & & & & & & 12 & & $\checkmark$ & $\checkmark$ & Micro & & WU & $8 \mathrm{hr} Q 4^{\circ} \mathrm{C}$ & 1 \\
\hline Respiraton Rates & 11 & & $\checkmark$ & $\checkmark$ & & & & & & $\checkmark 1$ & & $\checkmark$ & $\checkmark$ & Micro & & Ku & $8 \mathrm{hr} 04^{\circ} \mathrm{C}$ & 2 \\
\hline TTC Activity & $\checkmark 2$ & & $\checkmark$ & 1 & & & & & & 12 & & $\checkmark$ & $\checkmark$ & Micro & & KS & $8 \mathrm{hr} Q 4^{\circ} \mathrm{C}$ & 2 \\
\hline Metals 8 & $\checkmark$ & & & $\checkmark$ & & & & & & & & & & Lab & & $T M$ & $6 \mathrm{mn}$ acidffled $\mathrm{w} / \mathrm{HNO}_{3}, \mathrm{pH}<2$ & 2 \\
\hline BTEX 9 & $\checkmark$ & & 6 & & & & & & & & & & & & & & & \\
\hline $\mathrm{VOC}$ & & & & & $\sqrt{2}$ & & & 6 & $\checkmark$ & & & & & Lab \& Field & & $K Z+T M$ & & 2 \\
\hline $\mathrm{TPH}$ & $\checkmark 2$ & & $\checkmark$ & $\checkmark$ & $\sqrt{2}$ & & & & $\checkmark$ & 12 & & 1 & 1 & Lab \& Field & & $\mathrm{KZ}+\mathrm{TM}$ & ASAP, Max 14d $4^{\circ} \mathrm{C}$ & 1 \\
\hline TPHEXTRACT & 12 & & $\checkmark$ & 1 & $\sqrt{2}$ & & & & $\checkmark$ & $\checkmark 2$ & & 0 & 1 & Lab \& Field & & $\mathrm{KZ}+\mathrm{TM}$ & Extract $<14 \mathrm{~d} \&$ Anal $<40 \mathrm{~d}$ & 1 \\
\hline PAH & $\checkmark 2$ & & $\checkmark$ & $\checkmark$ & $\sqrt{2}$ & & & & $r$ & $\sqrt{2}$ & & & $\checkmark$ & Lab \& Field & & $K Z+T M$ & Extract $<14 d \&$ Anal $<40 d$ & 1 \\
\hline$\% \mathrm{CO2}$ & & & & & 12 & & $\checkmark 1,3$ & & & & & & & Fleld & & $K Z$ & N/A & 1 \\
\hline$\% \mathrm{CH}_{4}$ & & & & & $\checkmark 2$ & & $\checkmark 1,3$ & & & & & & & Fleid & & $K Z$ & N/A & 2 \\
\hline$\% \mathrm{He}$ & & & & & $\sqrt{2}$ & & $\checkmark 10$ & $\checkmark$ & & & & & & Field & & $K Z$ & $\mathrm{~N} / \mathrm{A}$ & 2 \\
\hline Moisture & 12 & $\checkmark$ & & & & & & & & & & & & Field & & $K Z$ & $N / A$ & 1 \\
\hline $\mathrm{NO} 2+3$ & $\checkmark 2$ & & $\checkmark$ & 5 & & & & & & $\checkmark 2$ & & $\checkmark$ & $\checkmark$ & Lab & & $\mathrm{TM}$ & ASAP, Max $24 \mathrm{hr} \bigcirc 4^{\circ} \mathrm{C} \&$ acidified $W / \mathrm{H}_{2} \mathrm{SO}_{4}$ & 2 \\
\hline $\mathrm{NH} 4$ & 12 & & $\checkmark$ & $\checkmark$ & & & & & & $\checkmark 2$ & & $\checkmark$ & $\checkmark$ & Lab & & $\mathrm{TM}$ & ASAP, Max $24 \mathrm{hr} \otimes 4^{\circ} \mathrm{C} \&$ acidified w/ $\mathrm{H}_{2} \mathrm{SO}_{4}$ & 2 \\
\hline TKN & $\checkmark 2$ & & $\checkmark$ & $\checkmark$ & & & & & & $\checkmark 2$ & & $\checkmark$ & $\checkmark$ & Lab & & $\mathrm{TM}$ & ASAP, Max $24 \mathrm{hr} \quad 4^{\circ} \mathrm{C} \&$ acidifled $w / \mathrm{H}_{2} \mathrm{SO}_{4}, 1.5<\mathrm{pH}<2$ & 2 \\
\hline$\%$ O2/Dissolved O2 & & & & & $\checkmark 2$ & & $\checkmark 1,3$ & & & $\checkmark 2$ & $\sqrt{2}$ & & $\checkmark$ & Field & & KZ & N/A & 1 \\
\hline $\mathrm{pH}$ & $\checkmark 2$ & & $\checkmark$ & 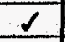 & & & & & & $\checkmark 2$ & $\checkmark$ & & & Lab \& field & & $K Z+T M$ & $6 \mathrm{mn}$ w/ 1 thymol crystal/200ml & 1 \\
\hline Redox Potential & & & & & & & & & & 12 & $\checkmark$ & & $\checkmark$ & Field & & $K Z$ & N/A & 3 \\
\hline Conductivity & & & & & & & & & & $\checkmark 2$ & 1 & & 1 & Field & & $K Z$ & $\mathrm{~N} / \mathrm{A}$ & 3 \\
\hline $\mathrm{PO}^{-3}$ & $\checkmark 2$ & & $\checkmark$ & $\checkmark$ & & & & & & $\checkmark 2$ & - & $\checkmark$ & $\checkmark$ & Lab & & $T M$ & ASAP or $-10^{\circ} \mathrm{C}$ & 1 \\
\hline TOTALP & 12 & & $\checkmark$ & $\checkmark$ & & & & & & 72 & & $\checkmark$ & $\checkmark$ & Lab & & $\pi M$ & ASAP or $-10^{\circ} \mathrm{C}$ & 2 \\
\hline $\mathrm{BOD}$ & $\checkmark 2$ & & $\checkmark$ & $\checkmark$ & & & & & & $\checkmark 2$ & & $\checkmark$ & $\checkmark$ & Lab & & $T M$ & ASAP, Max $24 h r @ 4^{\circ} \mathrm{C}$ & 2 \\
\hline$\infty$ & $\checkmark 2$ & & $\checkmark$ & $\checkmark$ & & & & & & $\checkmark 2$ & & $\checkmark$ & $\checkmark$ & Lab & & $T M$ & ASAP, Max $24 \mathrm{hr}-4^{\circ} \mathrm{C}$ unless acidified $\mathrm{w} / \mathrm{H}_{2} \mathrm{SO}_{4}, \mathrm{pH}<2$ & 2 \\
\hline Pressure \& Plezometers & & & & & $\checkmark 5$ & & $\checkmark 1,3$ & & $\checkmark$ & & & & & Field & & $\underline{K Z}$ & N/A & 1 \\
\hline Pressure Q Blower & & & & & $\checkmark 5$ & & 11,3 & & 1 & & & & & Field & & & N/A & 1 \\
\hline Temperature & $\checkmark 2$ & $\checkmark$ & & $\checkmark$ & & & & & & $\checkmark 2$ & $\checkmark$ & & $\checkmark$ & Field & & KZ & N/A & 1 \\
\hline Air Flow/Usage & & & & & & $\checkmark$ & & & & & & & & Field & & IZ & N/A & 1. \\
\hline Air Temp (Max/Min) & & & & & $\checkmark 5$ & & $\checkmark 1,3$ & & $\checkmark$ & & & & & Field & & $K Z$ & N/A & 2 \\
\hline Relative Humidity & & & & & $\checkmark 5$ & & 11,3 & & 1 & & & & & Field & & 12 & N/A & 2 \\
\hline Rainfall & & & & & $\checkmark 5$ & & $\checkmark 1,3$ & & 1 & & & & & Field & & $K Z$ & N/A & 2 \\
\hline Barometric Pressure & & & & & $\checkmark 5$ & & $\checkmark 1,3$ & & $\checkmark$ & & & & & Field & & 12 & N/A & 2 \\
\hline He Flow/Usage & & & & & $\checkmark 4$ & $\checkmark 6$ & & & & & & & & Field & & $K Z$ & $N / A$ & 2 \\
\hline
\end{tabular}

1 Resplration test.

2 Baseline data taken before injection starts.

3 Or after process change.

4 Tracer Test. Baseline data taken after injection starts. And after any process change or nonuniformity.

5 Baseline reading is taken after injection begins.

6 If Tracer Test is one day or less, flow should be recorded/adjusted at least every two hours. If test

lasts multiple days, flow should be recorded at least every four hours.

7 Aeroblc, anaerobic in passive zone only, $25^{\circ} \mathrm{C}, 45^{\circ} \mathrm{C}$

8 Only 4 random samples from Active Section and 4 random samples from Passive Section.

9 Baseline and monthly until <1ppm.

10 Weekly durlng Step Tests 
Czechowice Oil Refinery

Bioremediation Demonstration

Test Plan
WSRC-RP-97-214

Revision: 1

May 10, 1997

\subsection{Soil Gas Sampling Protocols}

The following protocol will be utilized for sampling soil gases. First, a magnehelic gage or other measuring device (the Landtec GEM 500 is equipped with an electronic pressure gauge) will be attached to the quick connect fitting for measurement of pressure. Second, a high volume pump approximately 5 liters per minute $(1 / \mathrm{min})$ will be attached to the quick connect and the well gas will be evacuated until oxygen readings have stabilized indicating that one is monitoring soil gas rather than well gases. Third, the Landtec GEM-500 or equal will be attached to a side stream of the vacuum pump and measurements of $\mathrm{O}_{2}, \mathrm{CO}_{2}$, and $\mathrm{CH}_{4}$ will be taken. Fourth, the Brüel \& Kjær multi-gas monitor will be used for the detection and analysis of VOCs including benzene, toluene and xylene(s) and the sVOC naphthalene. Laboratory and field analyses as seen in Table 4-2 will be performed by personnel at the IETU laboratory.

Helium tracer tests and vadose zone respiration measurements will be done using a Marks Helium Detector Model 9821(or equal) helium detector using the Bioventing Respiration Test protocols of EPA (EPA/540/R95/534a).

!

\subsection{Leachate Sampling Protocols}

A sampling port, pump or bailer will be used to collect leachate samples from the leachate recirculation system. Water will be filtered in the field, if required, with $45 \mu \mathrm{m}$ mesh filters. Field water parameters including dissolved oxygen, oxidation-reduction potential (ORP), $\mathrm{pH}$, specific conductivity, and temperature, will be monitored using the Hydrolab. The Hydrolab Surveyor probes used for estimation of dissolved oxygen and $\mathrm{pH}$ will be calibrated prior to each use. All other probes on the Hydrolab will be calibrated monthly.

Laboratory and field analyses will be performed by personnel at the IETU laboratory. Analytical methods (organics and inorganics) for leachate samples will be analyzed as noted for soils. Total VOC and carbon dioxide in leachate samples will be prepared and analyzed as follows. Leachate samples will be acidified in a serum bottle with a crimp seal septa. Thirty milliliters of leachate will be added to an amber serum bottle, capped and crimped in the field and held on ice until analyzed. One milliliter of concentrated hydrochloric acid will be added to serum bottles with a syringe, allowed to equilibrate, and then $2.5 \mathrm{ml}$ of headspace will be injected into a GC with a thermal conductivity detector (TCD). Standards will be made with sodium bicarbonate solutions (EPA Method 524.2).

The assays will be performed by the IETU with EPA approved methods. Soluble reactive phosphate concentrations will be measured by the ascorbic acid colorimetric determination method (EPA 365.2). Total Phosphorus will be determined by the persulfate digestion and ascorbic acid colorimetric determination (EPA 365.2). Total Nitrogen will be determined using a thermal conductivity detector (TCD which includes freeammonia plus organic nitrogen will be determined colorimetrically following digestion, distillation and Nesslerization method (EPA 351.3). Ammonia as distilled ammonia nitrogen will be determined colorimetrically following distillation and Nesslerization method (EPA 350.2). Nitrate, Nitrite, and Sulfate will be determined by the ion chromatography method (EPA 300.0). BOD and COD will be determined by 5day BOD test 5210 B APHA (1992) and the 5220B Open Reflux COD method APHA (1995).

\subsection{Analytical Procedures}

The EPA 8000 series analytical procedures found in Table 4.4 will be used in the analysis of soil samples. The use of these methods is now nearly universal in public and private sector laboratories. Each of these methods has an associated list of target compounds for which it was specifically developed and evaluated. 
These methods use gas chromatography (GC) and mass spectrometers (MS) or a combination of both GC/MS techniques to detect organic compounds. These instruments are well known for their excellent sensitivity and selectivity for specific target compounds.

Detection of complex hydrocarbon mixtures is best achieved using a $\mathrm{GC}$ with a flame ionization detector (GCFID). GC-FD analysis provides a more accurate representation of the degree of hydrocarbon contamination. EPA Method 418.1 does not provide information on the type of hydrocarbon contamination and the low boiling point components are easily lost. This method will only be used for screening purposes and final disposal will be governed by GC analysis.

The procedures outlined in Table 4-2 list different methodologies for the low to medium boiling point hydrocarbons (gasoline) and the high boiling point hydrocarbons (diesel motor fuels and light heating fuels). A purge and trap or head space is preferred for the more volatile contaminants whereas the high boiling point contaminants are to be analyzed using a GC-FID. The gas chromatographic analysis is equivalent to the well known "California Method" for testing TPHs for the Underground Storage Tank Program. For highly contaminated samples a waste dilution technique may be used but this must be documented with the analytical results.

! 
Czechowice Oil Refinery

Bioremediation Demonstration

Test Plan
WSRC-RP-97-214

Revision: 1

May 10, 1997

Table 4-2 Dissolved Hydrocarbons and Corresponding Methods of Analysis

\begin{tabular}{|c|c|c|}
\hline Analytical Group & Constituent & Analytical method \\
\hline \multirow{7}{*}{$\begin{array}{l}\text { Gasoline } \\
\text { (all motor gasoline } \\
\text { and Gasohol) }\end{array}$} & 1,2-dichloroethane & EPA Method 8010 \\
\hline & benzene & EPA Method 8020 \\
\hline & toluene & EPA Method 8020 \\
\hline & ethylbenzene & EPA Method 8020 \\
\hline & total xylenes & EPA Method 8020 \\
\hline & $\begin{array}{l}\text { total volatile organıc } \\
\text { aromatics }\end{array}$ & EPA Method 8020 \\
\hline & & $\begin{array}{l}\text { EPA Method } 5030 \\
\text { GC-FID California }\end{array}$ \\
\hline \multirow{5}{*}{$\begin{array}{l}\text { Middle distillates } \\
\text { (kerosene, diesel fuel } \\
\text { and light fuel oils) }\end{array}$} & naphthalene and & \\
\hline & other semivolatiles & EPA method 8270 \\
\hline & BTEX & EPA method 8020 \\
\hline & $n$-propylbenzene & EPA method 8020 \\
\hline & & GC-FID California 1 \\
\hline \multirow{4}{*}{$\begin{array}{l}\text { Other or unknown } \\
\text { metals }\end{array}$} & Priority pollutant & \\
\hline & & Toxicity \\
\hline & Characteristic & Leaching Procedure \\
\hline & Total Petroleum & EPA Method 9071 \\
\hline \multirow{2}{*}{ Hydrocarbons } & & with silica gel clean-up \\
\hline & & $\begin{array}{l}\text { EPA method } 418.1^{2} \\
\text { (screening only) }\end{array}$ \\
\hline
\end{tabular}

1. California Method: Leaking Underground Fuel Tanks Field Manual. Guidelines for Site Assessment, Clean-up and Underground Storage Tank Closure. State of California, May 1988.

2. Method 418.1 is no longer a recommended method by SCDHEC for final soil disposal determinations. However, this analytical method is acceptable for a preliminary screening process. 


\subsection{Microbiological Procedures}

Microbiological analyses will be done on a monthly basis. The soil samples from the biopile will be collected and processed on the same day the sampling was done. The first test will give total direct cell counts in the soil, utilizing DAPI (4, 6 Diamindino 2 phenylindole). This will provide a total bacterial cell count, expressed in cells per gram dry weight. The second analysis to be performed is a viable count, this will give the total number of organisms that can be cultured on an oligitrophic media. This number is expressed in colony forming units per gram dry weight. The third analysis is an enrichment for TPH. Bacteria will be grown on a minimal salts media with trace metals and TPH vapors as the only carbon source.

\subsubsection{4, 6 Diamindino 2 phenylindole (DAPI)}

DAPI will provide a direct estimate of the total number of bacteria in the environment, regardless of ability to grow on any media that might be used. Samples are preserved in phosphate buffered formalin. Samples (1 to 3 grams) are extracted three times with a non-ionic homogenizing detergent to remove bacteria from the sediment particles. Homogenates are cleared by low speed centrifugation and the supernatants pooled. Ten microliters of supernatant is spotted onto each well of a toxoplasmosis microscope slide, stained with 0.5 $\mu \mathrm{g} / \mathrm{ml}$ DAPI, then rinsed with distilled water. The number of cells stained with DAPI are counted by epifluorescence microscopy. The number of cells per sample is normalized by dividing by the dry weight of the sediment. Counts are reported as cells per gram weight (Kepner and Pratt, 1994). A comparison of acridine orange (AODC) stained samples and DAPI stained samples of soil obtained earlier from the refinery site showed the DAPI gave superior results (Ulfig, 1997)

\subsubsection{Calcofluor White (CFW) - optional}

CFW will provide a direct estimate of the total number of fungi in the environment, regardless of ability to grow on any media that might be used. Samples are preserved in phosphate buffered formalin. Samples (1 to 3 grams) are extracted three times with a non-ionic homogenizing detergent to remove bacteria from the sediment particles. Homogenates are cleared by low speed centrifugation and the supernatants pooled. Ten microliters of supernatant is spotted onto each well of a toxoplasmosis microscope slide, stained with Calcofluor White, then rinsed with distilled water. The number of cells stained with CFW are counted by epifluorescence microscopy. The number of cells per sample is normalized by dividing by the dry weight of

the sediment. Counts are reported as cells per gram weight (Santes et al., 1994). This assay may be deleted if samples become too difficult to count or they are not giving significantly better results for fungi than the DAPI technique.

\subsubsection{Naphthalene and Crude Oil Enrichment}

This method will provide an estimate of the total number of viable microbes capable of living in an enriched naphthalene and crude oil soil. Successful bioremediation of TPH/PAH can also be measured in terms of increased microbial activity, increased biomass; particularly biomass which contains TPH degrading enzymes, increased biomass capable of consuming TPH as evidence of stimulation by treatments. Minimal salts media (MSM) will be used (Fogel et al., 1986). The plates for naphthalene will be incubated in an enclosed environment with naphthalene vapors available to the bacteria as a source of carbon for metabolism (Davies and Evans, 1964). This count will also be in colony forming units per gram dry weight. As naphthalene will be the only carbon source available, this will be a count of these degraders only. For crude oil degraders MSM will be placed in 96 well microtiter plates. Samples will be diluted 10 fold across 8 wells in triplicate 
Czechowice Oil Refinery

Bioremediation Demonstration

Test Plan
WSRC-RP-97-214

Revision: 1

May 10, 1997

and a drop of crude oil placed in each well. After incubation each well be scored for turbidity and oil emulsification to obtain a most probable number (MPN) density per gram dry wt or per ml.

Since the passively aerated section of the biopile could become anaerobic, as could parts or micro-niches in the actively aerated section of the biopile, the enrichments will be done under both aerobic and anaerobic conditions. Anaerobic conditions will be maintained by Gas-Pak (a plate holder with a $\mathrm{CO}_{2}$ generator).

Since the actively aerated parts of the biopile could reach high temperatures due to high rates of biodegradation (composting type conditions). Enrichments from the active aeration side will be incubated both at $25^{\circ} \mathrm{C}$ and at $45^{\circ} \mathrm{C}$. This will insure that changes in temperature adaptation can be documented and that theromophilic degraders will not be underestimated.

\subsubsection{Microbial Dehydrogenase Activity - TTC}

Oxidation of petroleum by microbes like other types of organic oxidation under aerobic conditions is linked to

the electron transport system (ETS) of the cell. The enzymes of the ETS include a number of dehydrogenases,

i

thus dehydrogenase activity can be used as an overall measure of activity in the soil. Triphenyltetrazolium chloride (TTC) is used as an artificial electron acceptor to estimate dehydrogenase activity since the reduction of TTC to triphenyl formazan (TTF) causes a color change that can be quantified using a spectrophotometer. Soil samples will be incubated with TTC $(1.5 \mathrm{~g} / 100 \mathrm{ml})$ for $24 \mathrm{~h}$. The samples are then extracted with acetone and the extract measured at $546 \mathrm{~nm}$ using a spectrophotometer (Alef and Nannipieri, 1995) Values are presented as TPF $\mu \mathrm{g} / \mathrm{gdw}$.

\subsubsection{Respiration Rates}

Laboratory respiration rate measurements will also be taken as another source for the detection of carbon utilization by the TPH degraders. Alef and Nannipieri(1995) methods for soil respiration will be used to calculate the production of $\mathrm{CO}_{2}$ over a given period of time. Soil will be placed in a closed flask with a small solution of $\mathrm{NaOH}$ to act as $\mathrm{CO}_{2}$ trap. After incubation for several hours or more the $\mathrm{NaOH}$ is fixed with $\mathrm{BaCl}_{2}$, colored with phenolphthalein and titrated with a weak solution of $\mathrm{HCl}$ to determine the amount of $\mathrm{CO}_{2}$ produced. The results are reported as $\mathrm{mg} \mathrm{CO}_{2} / \mathrm{h} / \mathrm{gdw}$. This has already been demonstrated to work well for the refinery soils (Ulfig et al., 1997)

\section{HEALTH AND SAFETY}

The chemical hazards and health risks associated with this project have been evaluated through the risk assessment process. Based on the risk assessment a Health and Safety Plan (HASP) has been prepared. The HASP can be seen in Appendix C. As a minimum, to reduce the possibility of exposure, hand and foot protection in the form of work gloves (rubber gloves during sampling) and boots with shoe covers should be worn while working in the designated exclusion zone. The site Health and Safety Officer will provide daily guidance on dress-out requirements necessary to perform the assigned tasks.

\subsection{Other Safety Information.}

Other sources of safety information include: NIOSH Pocket Guide to Chemical Hazards, publication No. 90117, Federal Motor Carrier Safety Regulations Pocketbook, and WSRC Safety Guidelines for Subcontractors. 
Czechowice Oil Refinery

Bioremediation Demonstration

Test Plan
WSRC-RP-97-214

Revision: 1

May 10, 1997

\subsection{Quality Assurance/Quality Control}

All activities at the Czechowice Oil Refinery that are under the direction of WSRC personnel are governed by WSRC Quality Assurance Program as outlined in WSRC Management Policies, WSRC-1-01 MP 4.2. Site specific Quality Assurance Procedures are documented and controlled by the Czechowice Oil Refinery and the IETU as required. Additionally, any quality control inspection activities required to perform the tasks of this Test Plan shall by provided by the engineering staff of the Czechowice Oil Refinery. Additional field inspection support shall be provided by the IETU and WSRC as necessary.

\subsection{Security}

WSRC security requirements and procedures are documented in the WSRC Security Manual (7Q). These procedures are as required by Federal Laws and applicable DOE Orders, eg. DOE Order 5631.1A. These documents shall be in effect for WSRC employees.

6. Patents

The Office of Patent Counsel, DOE, prepared a Preliminary Patentability Search Report for the Prepared Bed Bioreactor design and the following patent references listed in Table 6.0 have been issued. Due to the similar nature of the project, the following patents are referenced.

Table 6-1 Related Patent References

\begin{tabular}{||c||c|c|c||}
\hline \hline PATENT & DATE & INVENTOR & SEARCH CLASS \\
\hline \hline $5,134,078$ & $07 / 92$ & Sieksmeyer, et al. & $432 / 262$ \\
\hline $5,128,262$ & $07 / 92$ & Lindoerfer, et al. & $435 / 262$ XR \\
\hline $4,962,034$ & $10 / 90$ & Khan & $435 / 262$ \\
\hline $4,871,673$ & $10 / 89$ & Rehm, et al. & $435 / 262$ \\
\hline $4,678,582$ & $07 / 87$ & Lavigne & $435 / 262$ \\
\hline $4,584,102$ & $04 / 89$ & Bogart, et.al & $405 / 128 \mathrm{XR}$ \\
\hline $4,447,541$ & $05 / 84$ & Peterson & $435 / 264$ \\
\hline
\end{tabular}

7. References

Alef, K., and P. Nannipieri. 1995. Methods in Applied Soil Microbiology and Biochemistry. Academic Press, New York. 576 pp.

Ames Laboratory. 1996. Report on the Results of the Expedited Site Characterization Demonstration at the Czechowice Refinery.

APHA. 1992. Standard Methods for the Examination of Water and Wastewater. 18th Ed. American Public Health Association. Washington, DC.

Atlas, R. M. 1984. Petroleum Microbiology. Macmillan Publishers, New York, NY.

Balkwill, D. L. 1989. Numbers, diversity, and morphological characteristics of aerobic, chemoheterotrophic bacteria in deep subsurface sediments from a site in South Carolina. Geomicrobiol. J. 7:33-52. 
Bartha, R., and I. Bossert. 1984. Treatment and Disposal of Petroleum Refinery Wastes. In: R. M. Atlas (ed.), Petroleum Microbiology. Macmillan Publishers, New York, NY.

Brüel \& Kjær. 1996. Operating Manual for the Model 1302. Brüel \& Kjær, 2850 Nærum, Denmark.

Czechowice Oil Refinery, 1995. Public relations and historical information brochure. Czechowice-Dziedzice, Poland.

ECOVA. 1989. Solid Phase Bioremediation. ECOVA Corporation, Redmond, WA.

FSU. 1995. Program Plan for the United States Department of Energy and Institute for Ecology of Industrial Areas Partnership. Ed., J. M. Kuperberg. Institute for Central and Eastern European Cooperative Environmental Research. Florida State University, Tallahassee, Florida.

Fogel, M. M., A. R. Taddeo, and S. Fogel. 1986. Biodegradation of chlorinated ethenes by a methaneutilizing mixed culture. Appl. Environ. Microbiol. 51:720-724.

Hazen, T. C. 1991. Test Plan for In situ Bioremediation Demonstration of the Savannah River Integrated Demonstration Project, DOE/OTD TTP No.: SR 0566-01. Technical Report WSRC-RD-91-23. 82 pp. WSRC Information Services, Aiken, SC.

Huis in't Veld, M. G. A., J. Werners, J. J. van Veen and H. J. Doddema. 1995. Biological PAH Degradation in Dredged Sludges, pp. 17-22. In: Bioremediation of Recalcitrant Organics, R. E. Hinchee (ed). In situ and On-Site Bioreclamation, The Third International Symposium. San Diego, CA.

IETU. 1994. Institute for Ecology of Industrial Areas Annual Report. Katowice, Poland.

IETU. 1996. GIS Mapping Department. Institute for Ecology of Industrial Areas. Katowice, Poland.

Jagosz, B. 1995. Personal communication. Chief Engineer, Czechowice Oil Refinery. CzechowiceDziedzice, Poland.

Kepner, R. L., and J. R. Pratt. 1994. Use of fluorochromes for direct enumeration of total bacteria in environmental samples: past and present. Microbiol. Rev. 58:603-615.

Laczny, M. J. 1983. A Model of Groundwater Contamination from a Power Station Solid Waste Landfill. Institute for Environmental Protection. Katowice, Poland. ISBN 83-85-002-32-4.

Landfill Control Technologies. 1996. GEM-500 Operation Manual. Landfill Control Technologies, 6055 E. Washington Blvd., Commerce, CA 94110

Molnaa, B. A., and R. B. Grubbs. 1989. Bioremediation of Petroleum Contaminated Soils Using a Microbial Consortia as Inoculum. In: E. J. Calabrese \& P. T. Kostecki (eds.), Petroleum Contaminated Soils, vol. 2. Lewis Publishers, Chelsea, MI.

Preslo, L. M., Leis, W. M., and Pavlick, R. 1990. In: Petroleum Contaminated Soils, Vol. 2, p. 111. (Kostecki, P. T., and Calabrese, E. J., Eds.). Lewis Publishers, Chelsea, MI.

Przedsiebiorstwo Geodezyjno-Kartograficzne. 1996. Local map with historical description of the region. Katowice, Poland. 
Czechowice Oil Refinery

Bioremediation Demonstration

Test Plan
WSRC-RP-97-214

Revision: 1

May 10, 1997

Reisinger, H. J., S. A. Mountain, G. Andreotti, G. DiLuise, A. Porto, A. Hullman, V. Owens, D. Arlotti, and J. Godfrey. in press. Bioremediation of a Major Inland Oil Spill Using a Comprehensive Integrated Approach. Proceedings: Third International Symposium and Exhibition on Environmental Contamination in Central and Eastern Europe. September, 1996.

Ross, D., T. P. Marziarz, and A. L. Bourquin. 1988. Bioremediation of Hazardous Waste Sites in the USA: Case histories. In: Superfund '88, Proc. 9th National. Conference. Hazardous Materials Control Research Institute, Silver Spring, MD.

Sims, R. C. 1986. Loading Rates and Frequencies for Land Treatment Systems. In: R. C. Loehr and J. F. Malina, Jr., (eds.) Land Treatment: A Hazardous Waste Management Alternative. Water Resources Symposium No. 13, Center for Research in Water Resources, The University of Texas at Austin, Austin, TX.

Sinclair, J. L., and W. C. Ghiorse. 1989. Distribution of aerobic bacteria, protozoa, algae, and fungi in deep subsurface sediments. Geomicrobiol. J. 7:15-32.

South Carolina Department of Health and Environmental Control. 1992. Petroleum Hydrocarbon Analytical

! Methodology for Ground Water and Soil Assessment. Laboratory Certification Section, P.O. Box 72, State Park, South Carolina 29147.

St. John, W. D., and D. J. Sikes. 1988. Complex Industrial Waste Sites. In: G. S. Omenn (ed.), Environmental biotechnology. Reducing Risks from Environmental Chemical through Biotechnology. Plenum Press, New York, NY.

Ulfig, K., G. Plaza, T. C. Hazen, C. B. Fliermans, M. M. Franck, and K. H. Lombard. in press. Bioremediation Treatability and Feasibility Studies at a Polish Petroleum Refinery. Proceedings: Third International Symposium and Exhibition on Environmental Contamination in Central and Eastern Europe. September, 1996.

U.S. Department of Health and Human Services. 1990. NIOSH Pocket Guide to Chemical Hazards. Public Health Service. Centers for Disease Control. National Institute for Occupational Safety and Health. Superintendent of Documents, U.S. Government Printing Office, Washington D.C. 20402.

U.S. Department of Transportation (USDOT). 1989. Federal Motor Carrier Safety Regulations Pocketbook. J. J. Keller and Associates, Inc., Pub. Neenah, Washington 54957-0368.

U.S. Environmental Protection Agency (USEPA). 1995. Manual: Bioventing Principles and Practice. Vol 1 and 2. EPA/540/R-95/534a. Office of Research and Development Washington, DC 20460.

U.S. Environmental Protection Agency (USEPA). 1985. Compilation of Air Pollutant Emission Factors. AP-42, Fourth Edition. Office of Air Quality, Research Triangle Park, NC 27711.

U.S. Environmental Protection Agency (USEPA). 1986. Test Methods for Evaluating Solid Wastes, Physical/Chemical Methods. SW-846, $3^{\text {rd }}$ edition. Superintendent of Documents, U.S. Government Printing Office, Washington D.C. 20402.

U.S. Environmental Protection Agency (USEPA). 1987. Industrial Source Complex (ISC) User's Guide; Second Edition (Revised). EPA-450/2-78-027R. Office of Air Quality, Research Triangle Park, NC 27711 .

U.S. Environmental Protection Agency (USEPA). 1988. A Workbook of Screening Techniques for Assessing Impacts of Toxic Air Pollutants. EPA-450/4-88-009. Office of Air Quality, Research 
Triangle Park, NC 27711.

Vanderlaan, M., Stanker, L. H., and Watkins, B. E. 1990. In: Immunoassays for Trace Chemical Analysis, p. 2. (Vanderlaan, M., Stanker, L. H., Watkins, B. E. and Roberts, D. W., Eds.) Washington, D.C., American Chemical Society.

Watts, J. R., and J. C. Corey. 1982. Land Application Studies of Industrial Waste Oils. Environ. Pollution (Series A). 28:165-175.

Westinghouse Savannah River Company. Safety Guidelines for Subcontractors. Pocket handbook. Issued through SRS Safety Department.

? 


\section{Appendix A}

\section{List of Acronyms and Abbreviations}

$\begin{array}{ll}\text { APR } & \text { Air Purifying Respirator } \\ \text { B\&K } & \text { Brüel \& Kjær } \\ \text { BETX } & \text { Benzene, Ethyl Benzene, Toluene and Xylene } \\ \text { bgs } & \text { below ground surface } \\ \text { bp } & \text { Boiling Point } \\ \text { CFU } & \text { Colony Forming Units } \\ \text { CH } & \text { Fat clay or very fine high plasticity clay } \\ \text { CL } & \text { Fine grained clay of low to medium plasticity } \\ \text { COC } & \text { Contaminants Of Concern } \\ \text { COR } & \text { Czechowice Oil Refinery } \\ \text { DAPI } & \text { 4,6 Diamindino 2 phenylindole } \\ \text { DOE } & \text { United States Department of Energy } \\ \text { ESC } & \text { Expedited Site Characterization } \\ \text { FID } & \text { Flame Ionization Detector } \\ \text { FSU } & \text { Florida State University } \\ \text { GC } & \text { Gas Chromatography } \\ \text { GPR } & \text { Ground Penetrating Radar } \\ \text { GW } & \text { Coarse grained gravel sand mixture } \\ \text { HASP } & \text { Health and Safety Plan } \\ \text { IETU } & \text { Institute for Ecology of Industrial Areas } \\ \text { ISCST } & \text { Industrial Source Complex /Screening Techniques } \\ \text { LEL } & \text { Lower Explosive Limit } \\ \text { LUST } & \text { Leaking Underground Storage Tank } \\ \text { NIOSH } & \text { National Institute of Occupational Health and Safety (USA) } \\ \text { OSHA } & \text { Occupational Safety and Health Act (USA) } \\ \text { ORP } & \text { Oxidation-Reduction Potential } \\ \text { PAH } & \text { Polycyclic Aromatic Hydrocarbon } \\ \text { RACE } & \text { Risk Abatement Center for Central and astern Europe } \\ \text { SCDHEC } & \text { South Carolina Department of Health and Environmental Control } \\ \text { SPM } & \text { Single Point Monitor } \\ \text { SRS } & \text { Savannah River Site } \\ \text { SRTC } & \text { Savannah River Technology Center } \\ \text { SSO } & \text { Site Safety Officer } \\ \text { TCD } & \text { Thermal Conductivity Detector } \\ \text { TOC } & \text { Total Organic Carbon } \\ \text { TPH } & \text { Total Petroleum Hydrocarbons } \\ \text { USEPA } & \text { U.S. Environmental Protection Agency } \\ \text { VOC } & \text { Volatile Organic Hydrocarbon } \\ \text { SVOC } & \text { Semi-Volatile Organic Hydrocarbon } \\ \text { WSRC } & \text { Westinghouse Savannah River Company } \\ & \\ & \end{array}$


Czechowice Oil Refinery

Bioremediation Demonstration

Test Plan

Appendix B

Biopile Design
WSRC-RP-97-214

Revision: 1

May 10, 1997 


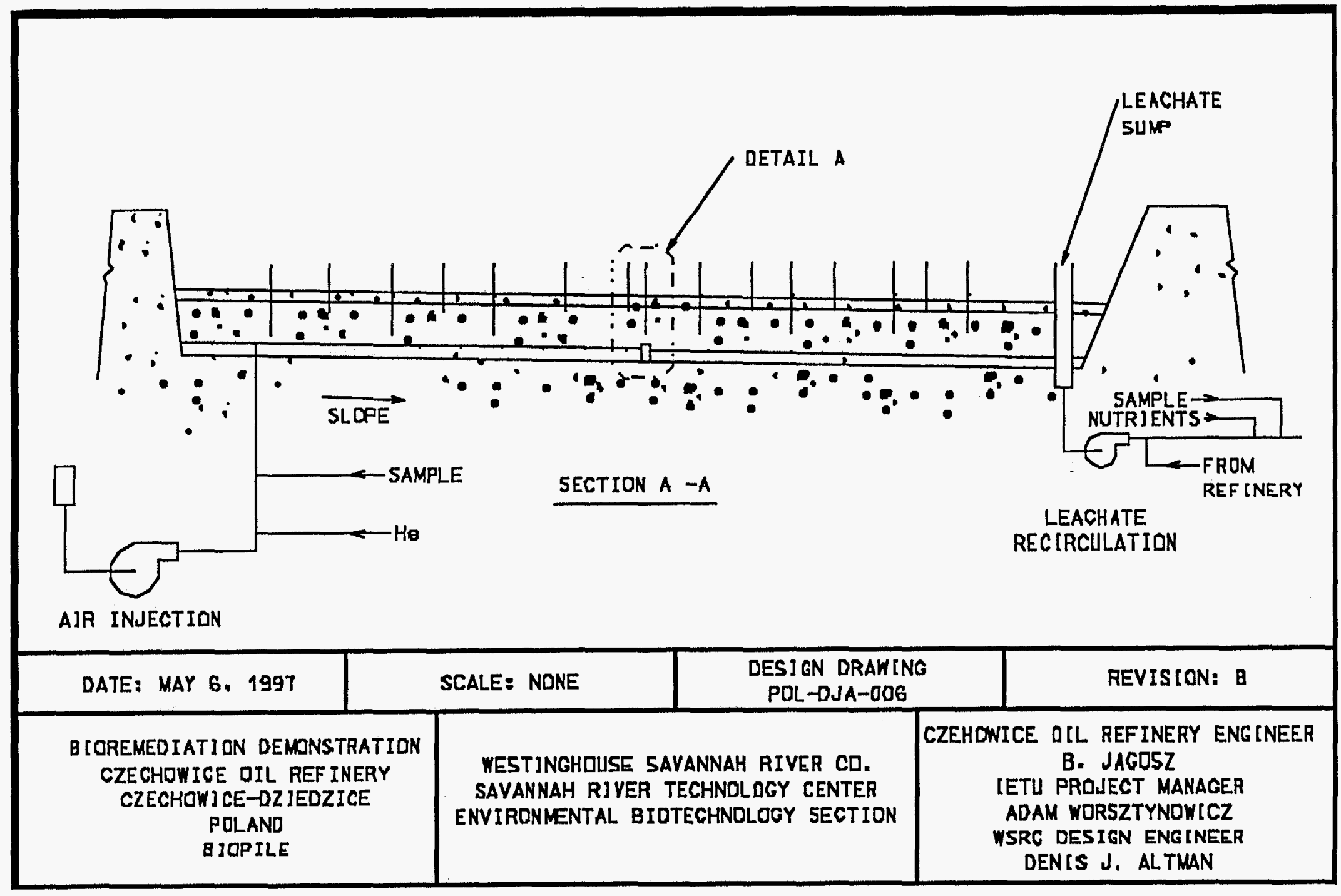




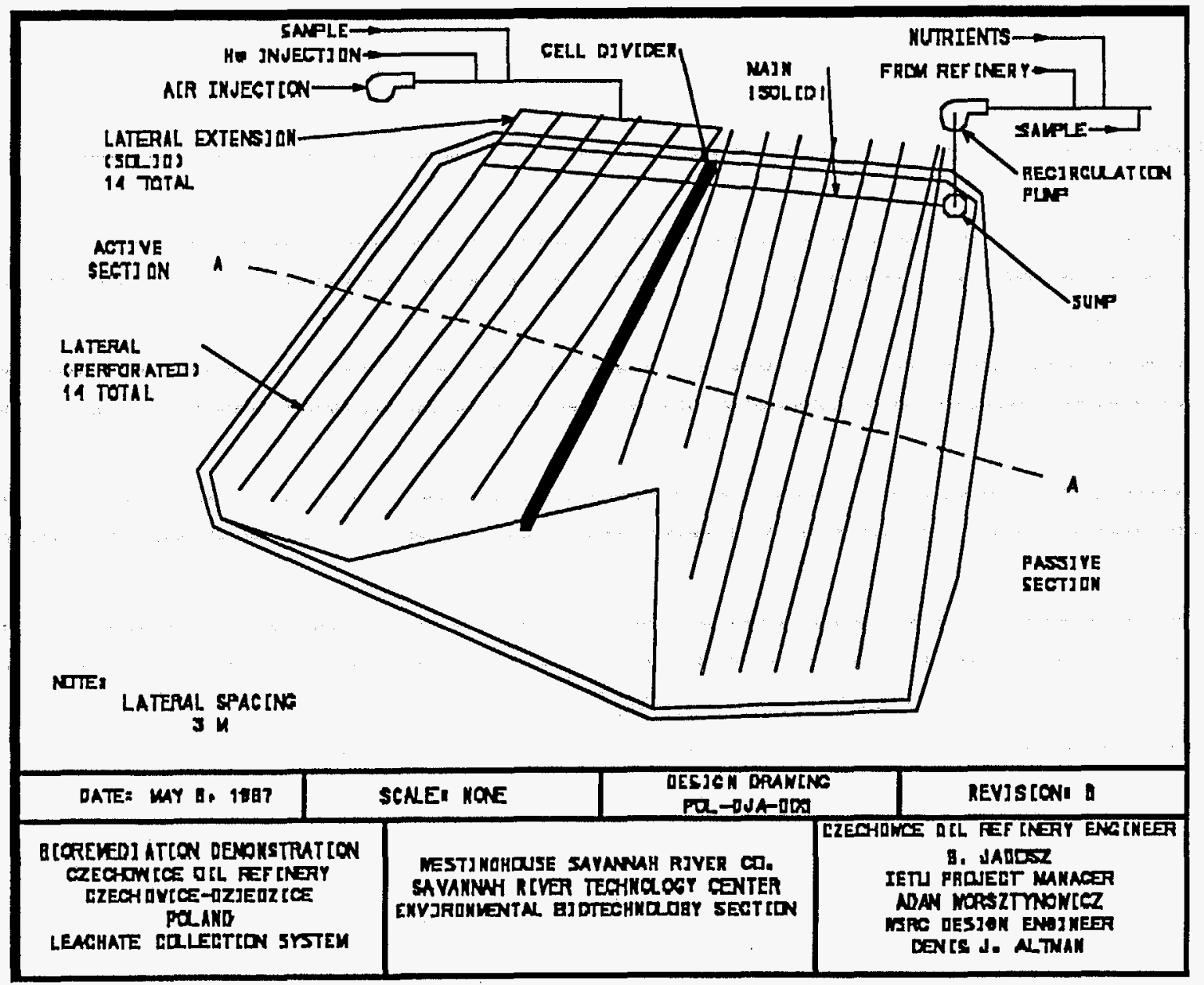




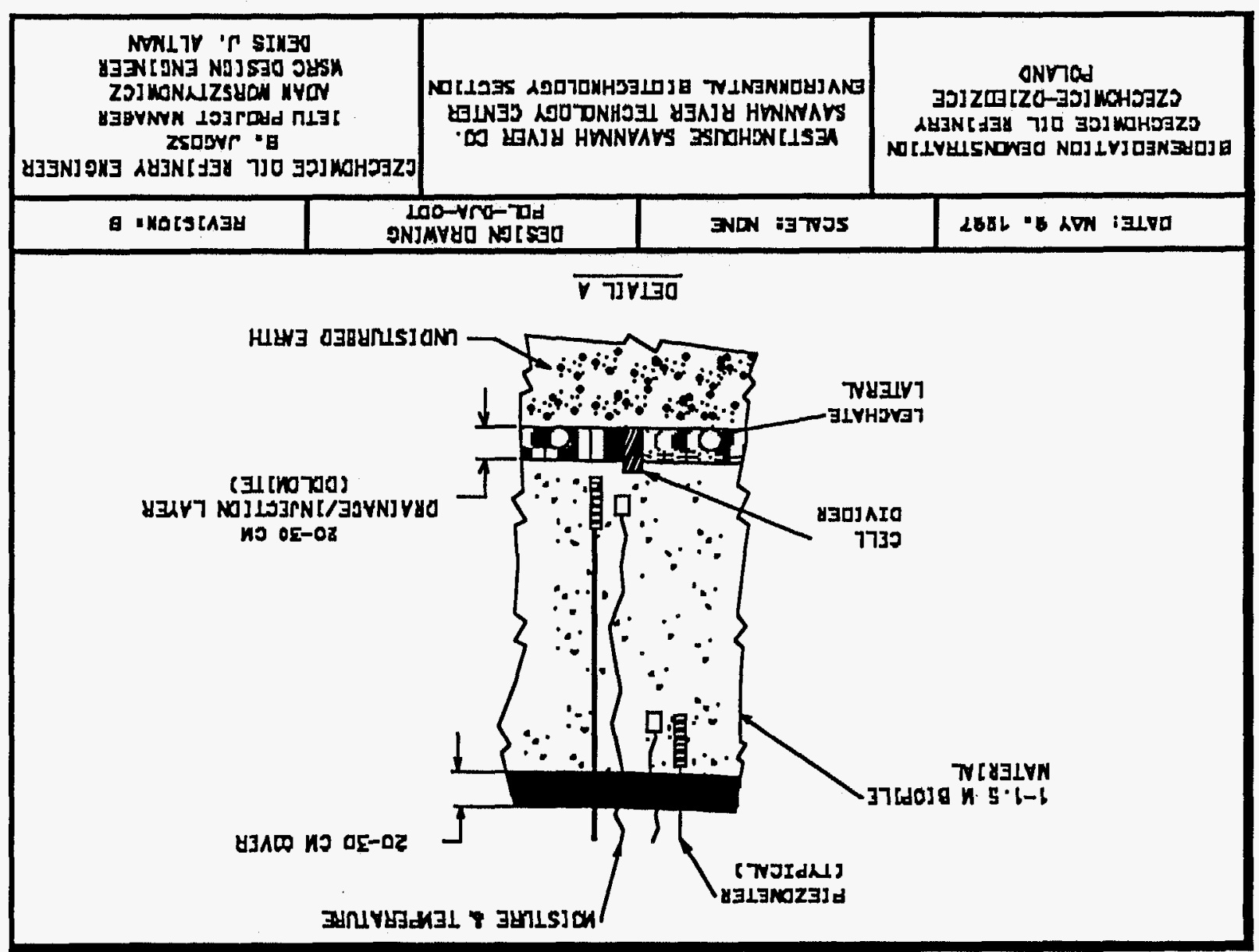




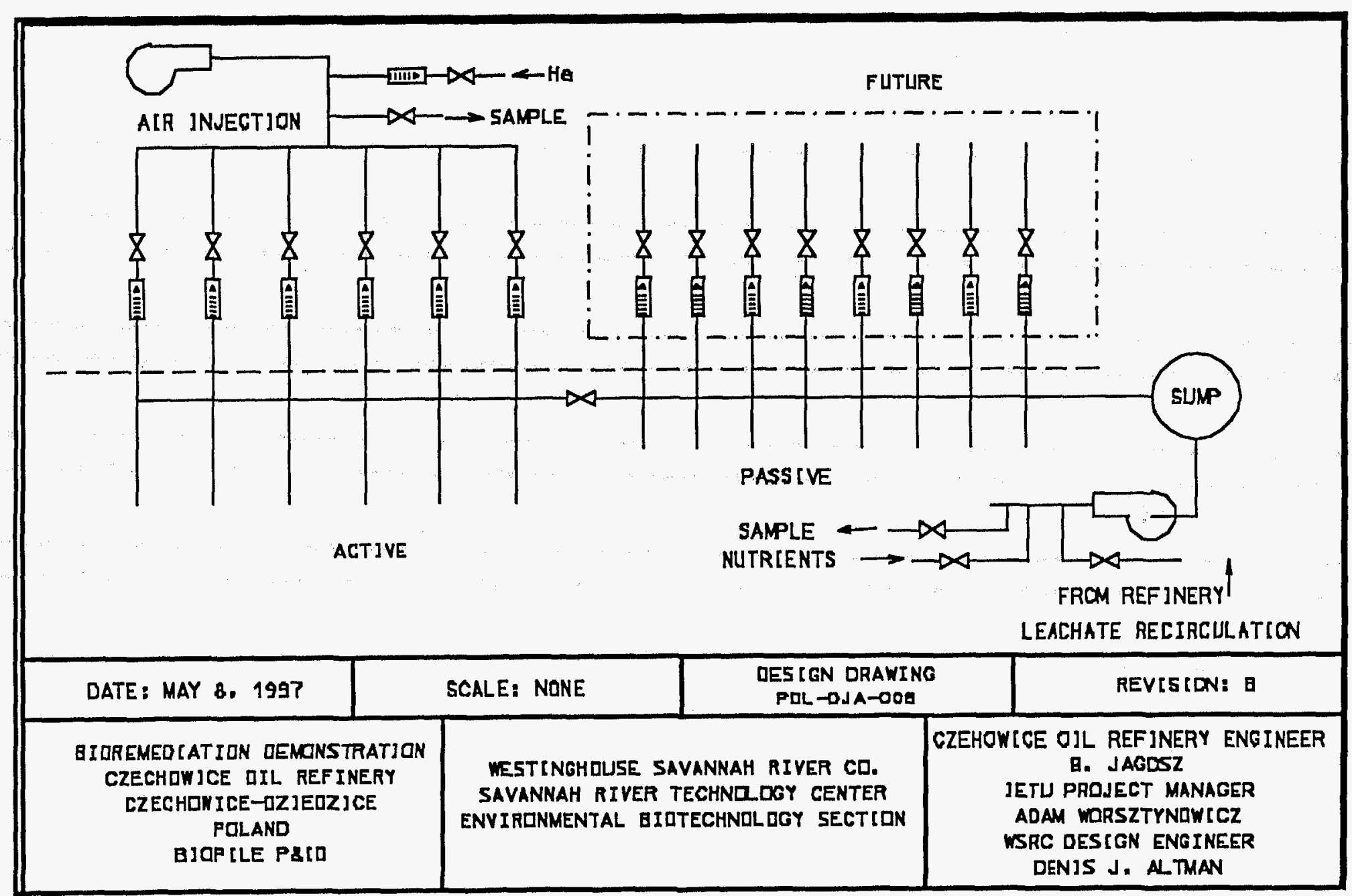


Czechowice Oil Refinery

Bioremediation Demonstration

Test Plan

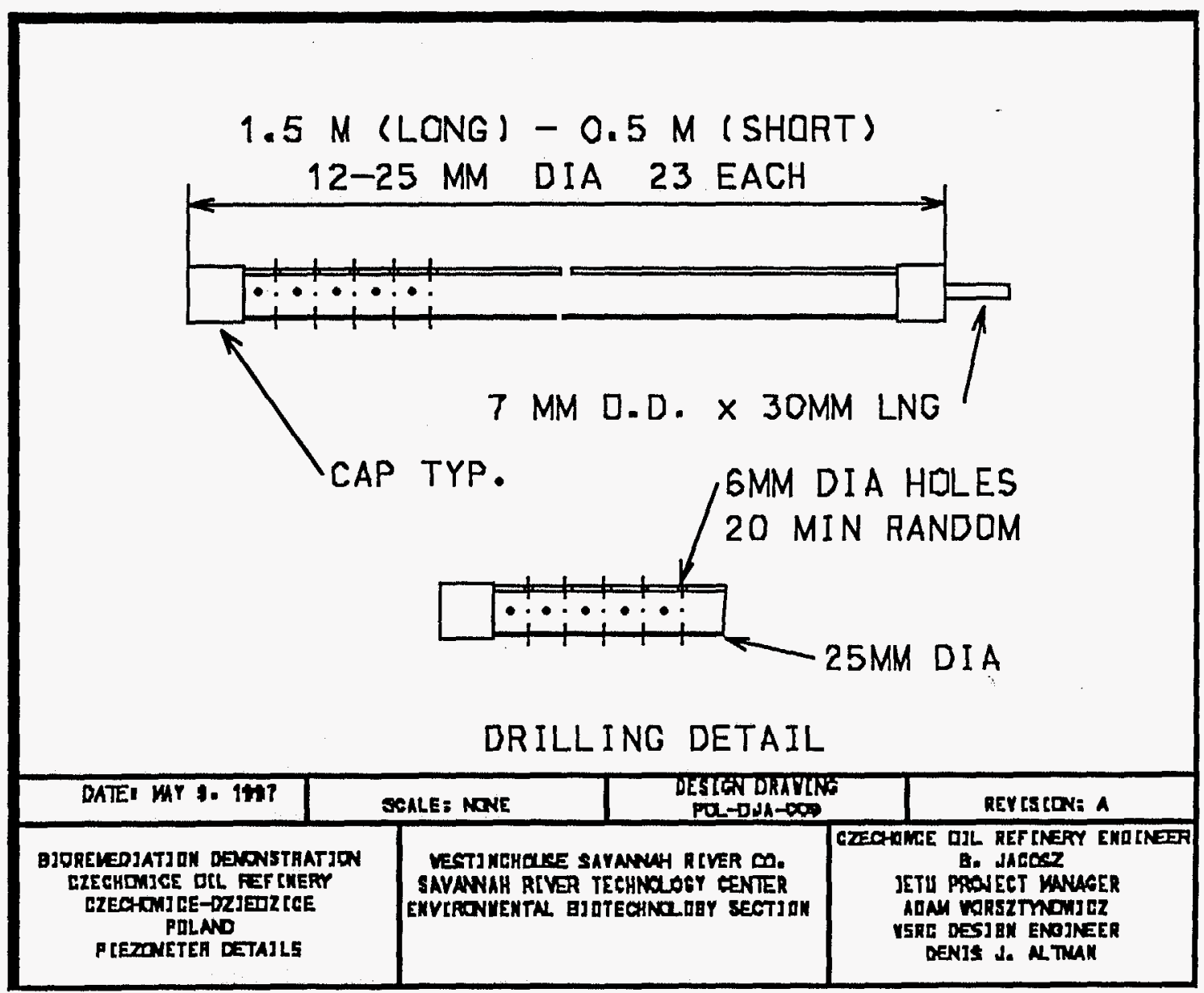


Czechowice Oil Refinery

Bioremediation Demonstration

Test Plan

Appendix C

List of Materials and Equipment
WSRC-RP-97-214

Revision: 1

May 10, 1997 
Czechowice Oil Refinery

Bioremediation Demonstration

Test Plan
WSRC-RP-97-214

Revision: 1

May 10, 1997

\section{LIST OF MATERIALS AND EQUIPMENT}

DOLOMITE:

Size: $10-30 \mathrm{~mm}$

Quantity: $880 \mathrm{t}$

Price: $17.90 \mathrm{z} 3 / \mathrm{t}+22 \%$ VAT $=21.84 \mathrm{z} 3 / \mathrm{t}$

Transport: from a quarry located at Siewierz, Bacholiñska Str. 11, tel. 1226037

WOOD CHIPS:

Quantity: $250 \mathrm{~m}^{3}$

Price: negotiable

Transport: from a saw- mill located at Kobiór, Centralna Str., tel. 1188064

HUMUS:

Quantity: $500 \mathrm{~m}^{3}$

GRASS SEED:

Quantity: $\sim 10 \mathrm{~kg}$ (A mixture of: 40\% Dactylis glomerata L., 40\% Festuca pratensis Huds., 20\% Lolium multiflorum Lam.)

DRAINAGE PIPES:

Total length: $510 \mathrm{~m}$

CERAMIC:

Tubes: dia. $10 \mathrm{~cm}, \sim 30 \mathrm{~cm}$ long

Price: $1.07 \mathrm{z} 3 /$ piece $=3.21 \mathrm{z} 3 / \mathrm{m}$.

PLASTIC:

Pipes: dia $10 \mathrm{~cm}, 50 \mathrm{~m}$. long

Price: $3.50 \mathrm{z} 3 / \mathrm{m}$.

Transport from a wholesale dealer: Pustelnik, Wis3a Ma3a, tel. 1123492

AIR BLOWER:

Capacity: $\sim 500 \mathrm{~m}^{3} / \mathrm{hr}$ at $1.27 \mathrm{~m} . \mathrm{H}_{2} \mathrm{O}$

Type: Sweetwater S.73

Delivered by WSRS

LEACHATE CIRCULATION PUMP:

Capacity: TBD

Type: TBD

SUMP, MAIN, LATERAL EXTENSIONS AND OTHER PIPING, SOAK HOSE: TBD, according on what is available at the Refinery.

PIEZOMETERS:

23 piezometers $1.5 \mathrm{~m}$. long

23 piezometers $0.5 \mathrm{~m}$. long

Material: metal or plastic

Diameter: 12 - $25 \mathrm{~mm}$

Total length: $46 \mathrm{~m}$

Will be manufactured by the Refinery according to delivered drawings. 
Czechowice Oil Refinery

WSRC-RP-97-214

Bioremediation Demonstration

Revision: 1

Test Plan

INSTRUMENTATION:

VALVES:

Amount:

Aeration system: 6

Leachate circulation system: 1

Make-up water: 1

Helium injection: 1 (small)

Nutrients injection: 1 (small)

Sampling: 2 (small)

Diameters and material: TBD, according to what is available at the Refinery

FLOWMETERS:

Amount:

Aeration system: 6 (measurement range: $0-10 \mathrm{~m}^{3} / \mathrm{hr}$ )

Helium injection: 1

TERMOMETERS:

Amount: 46

MOISTURE BLOCKS:

Amount: 46

HELIUM FLOW REGULATOR:

Amount: 1 
Czechowice Oil Refinery

Bioremediation Demonstration

Test Plan

\section{Appendix D}

Column Study
WSRC-RP-97-214

Revision: 1

May 10, 1997

! 
Experimental Plan for Biodegradation Studies with Columns using Soils Contaminated by Refinery Process Wastes

\section{A. J. Tien and M. Adamski}

\section{Introduction}

Nutrient-limitation or availability of appropriate electron acceptors can hamper natural biodegradative processes at contaminated sites. In laboratory studies often high rates of degradation of refinery wastes are reported. Unfortunately, this is due, in part, to the highly controlled and optimal conditions provided ( $\mathrm{pH}$, temperature, nutritional balance, ideal mixing etc.) in these laboratory systems. At many contaminated sites, including the Czechowice Refinery, the problem of varying soil structure, contaminant concentration and type of contaminants make the determination of bioremediation strategies difficult. These hetrogeneities also lead to problems with mass transfer (the supply of appropriate nutrients i.e., phosphate, nitrogen, oxygen, water, etc.). An intermediate step between batch laboratory degradation studies and actual field remediation is the use of soil columns containing contaminated soil from the site of interest. Use of this type of system can provide essential information in determining operational parameters i.e., fine tuning, for rational engineering and construction of field scale systems to overcome problems with mass transfer and nutrient availability. Furthermore, data obtained from column studies can be applied to biodegradation simulation models which may be used and compared with actual data from field scale studies.

\section{Approach}

Soil columns will be used to observe in situ biodegradation under controlled laboratory conditions to simulate the cross-sectional operations of the biopile system. Benefits of this approach are that through the use of a smaller scale, potential design problems may be seen and modified and that multiple parameters can be simultaneously tested. Additionally, optimization of certain operational parameters (e.g. air flow, moisture, hydraulic conductivity and nutrient amendments) can be first established with the columns before actual implementation in the field. In this study, a comparison between air supply (passive vs. active) and nutrient amendments (with vs. without) and their effect on biodegradation rates will be studied. Constant measurement of contaminant concentration and microbial numbers and activity will give direct evidence of column performance. Monitoring of column temperature is also useful, since as microbial activity increases, the temperature of the columns will also increase. Measurement of soil gas composition is also very important and can give inferential evidence on efficiency of air supply. If methane is detected, increased air flow rates will be necessary to overcome anaerobic conditions. Data from initial site characterization and column studies will be imported to biodegradation modeling programs and later compared with results from actual biopile operations.

\section{Experimental System}

The scale of the column experiments as compared to the biopile is approximately $1: 1$ in depth. Four, 2 meter by $30 \mathrm{~cm}$ diameter Plexiglas columns filled with contaminated refinery soil will be used. In three of the columns, an active ventilation system, where air is injected from the base of the column apparatus, will be used. Air flow will be controlled with airflow regulator/meters. In the fourth column, a passive air injection system via Baro-ball ${ }^{\mathrm{TM}}$ will be employed (See Fig 1 for schematic of experimental set up). As with the preliminary biopile design, the first $20 \mathrm{~cm}$ of the column fill will consist of dolomite aggregate which will serve two purposes; diffusion of the 
Czechowice Oil Refinery

Bioremediation Demonstration

Test Plan
WSRC-RP-97-214

Revision: 1

May 10, 1997

injected air (active system only) and as a pH buffering agent. The next $110 \mathrm{~cm}$ will be composed of a mixture of contaminated refinery soil and wood chips $(10 \% \mathrm{v} / \mathrm{v})$. The wood chips will serve as a bulking agent to improve hydraulic conductivity and act as a moisture sink. The upper most $20 \mathrm{~cm}$ will be filled with topsoil and possibly seeded with grass. Soil moisture will be monitored using a soil moisture testing system with two sensors, one placed near the top and the other placed near the bottom of the column. Leachate water will be recirculated to maintain soil moisture and reseeding of pollutant degrading microorganisms. A perforated PVC pipe underneath the topsoil layer supplying leachate will minimize risk of aerosolization of microorganisms contained in the leachate (detail not shown). Five sampling ports will provide access for measurement of temperature and soil samples for chemical and microbiological examination (see Fig. 2 for blow up detail of single column).

\section{Analytical and Microbial Methods}

Soil samples from the column will be analyzed for BTEX, PAH, total petroleum hydrocarbon, extractable petroleum hydrocarbon. Initial available nitrogen and phosphorous levels will be measured in the soils samples and leachate using EPA methods. Conductivity and $\mathrm{pH}$ of the leachate will be monitored using pocket field instruments. DOC of leachate will be measured by Standard Methods. Total cell counts will be performed using DAPI direct counts with both soil and leachate. In addition, enrichment counts will also be performed using vapor or direct enrichment techniques. Microbial activity will be monitored using the TTC technique. Oxygen, methane and carbon dioxide will be measured using the LandTec field measuring device. Soil moisture will be monitored using the Delmhorst soil moisture system. Temperature within the soil column will be measured using a digital pocket field thermometer. ( for more details on sample preparation and analysis, please refer to the Test Plan).

\section{Sampling Plan}

Ongoing chemical and microbiological analysis of the soil column horizon and leachate are important for evaluation of column performance. As shown in Fig 2., five sampling ports along the column transitional profile have been chosen to allow for various measurements from the topsoil horizon, the transition zone between topsoil and contaminated soil, mid-horizon of the contaminated soil layer, the transition zone between the contaminated soil layer and the dolomite aggregate zone, and mid-horizon of the dolomite aggregate zone. Additionally, a sampling valve has been installed for easy access to leachate before recirculation. Samples and type of analytics are divided into those taken for initial baseline measurements, weekly measurements and those performed only on a monthly basis.

Baseline Measurements: Topsoil - TPH, exTPH, soil gases, DAPI, enrichments, TTC, temperature.

Contaminated soil - BTEX, PAH, TPH, exTPH, moisture, soil gases, DAPI, enrichments, TTC, temperature.

Dolomite layer - TPH, exTPH, soil gases, DAPI, enrichments, TTC, temperature.

Leachate - exTPH, DAPI, enrichments, TTC, $\mathrm{pH}$, conductivity, temperature, DOC.

Weekly Measurements: Topsoil - exTPH, soil gases, DAPI, TTC, temperature.

Contaminated soil - TPH, exTPH, moisture, soil gases, DAPI, TTC, temperature.

Dolomite layer - exTPH, soil gases, DAPI, temperature

Leachate - exTPH, DAPI, TTC, pH, conductivity, temperature, DOC. 
Czechowice Oil Refinery

Bioremediation Demonstration

Test Plan
WSRC-RP-97-214

Revision: 1

May 10, 1997

Monthly Measurements: Topsoil - Trapped carbon dioxide evolution

Contaminated soil - BTEX, PAH, TPH, enrichments

(24hrs).

Dolomite layer - no extra tests

Leachate - enrichments

\section{Computer Models}

The following computer modeling programs which simulate and predict the fate of pollutants during bioremediation in the field will be used: BioPlume II, ModFlow, and possibly BioScreen. In these programs, various parameters such as pollutant concentration, pollutant diffusion coefficients, airflow rate, moisture, available nutrients (nitrogen, phosphate, etc.), and biodegradation rates are taken into account. All of these parameters can be obtained from baseline studies using samples collected at the refinery or from the column experiments. Use of these models can also aid in the fine tuning of biopile operations. 
Czechowice Oil Refinery

Bioremediation Demonstration

Test Plan
WSRC-RP-97-214

Revision: 1

May 10, 1997

Figure 1. Schematic set-up of the column system
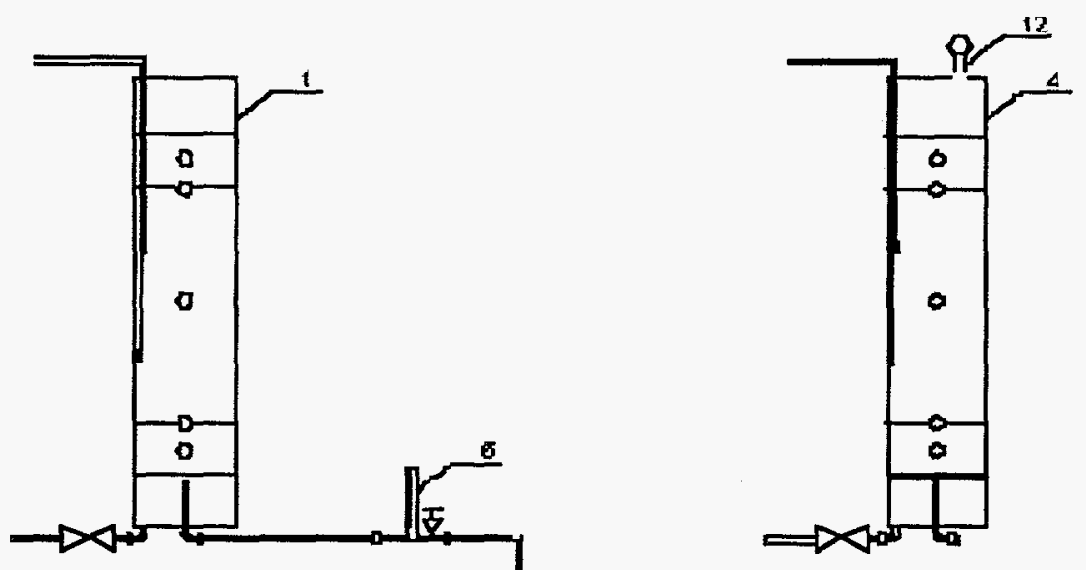

$\xi$

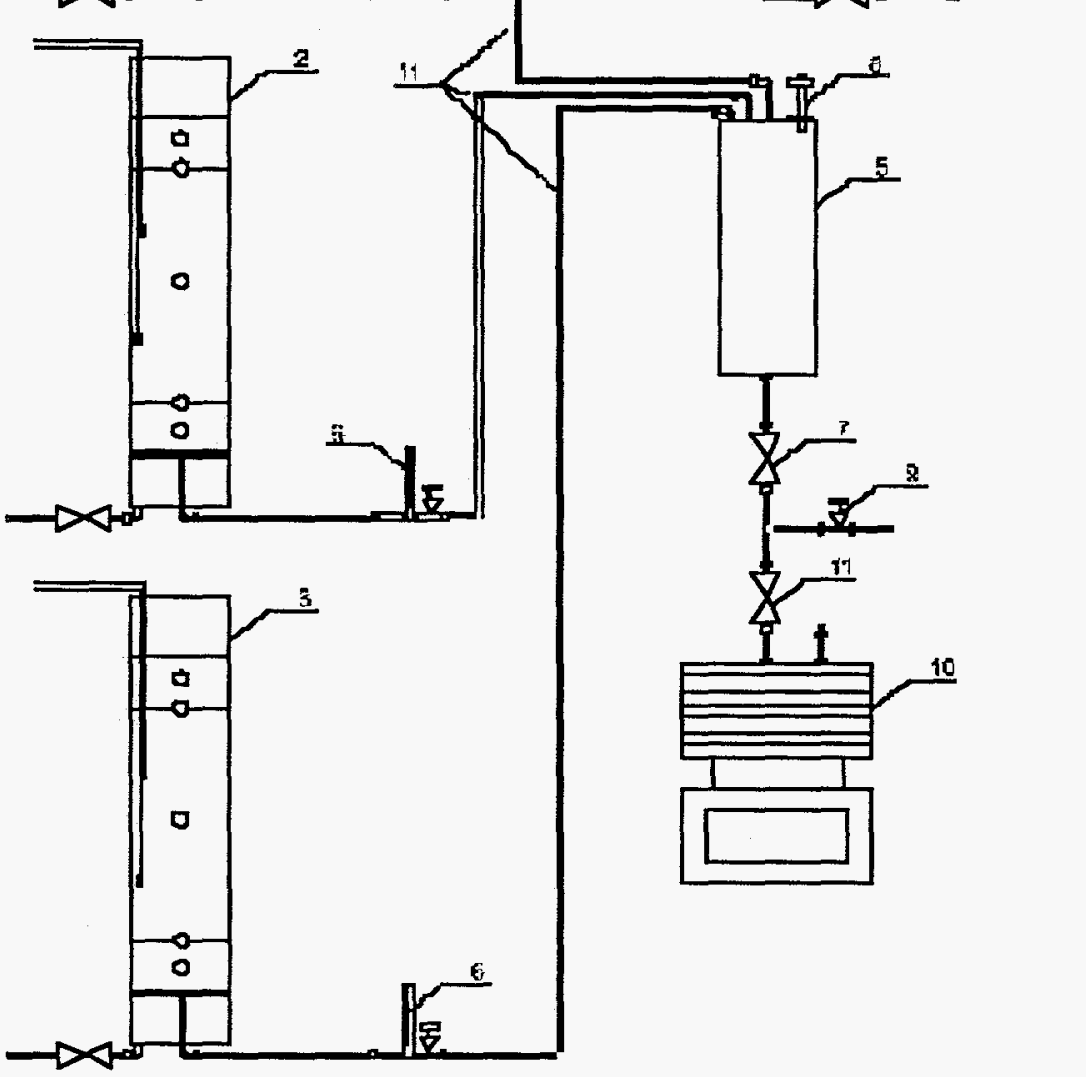

Figure Legends

\begin{tabular}{|c|c|c|c|c|c|}
\hline $1-3$ & $\begin{array}{l}\text { Active columns } \\
\text { interrupter }\end{array}$ & & 7 & Stop valve & 11. Backflow \\
\hline 4 & Passive column & & 8 & Blowout valve & 12. Baro-ball ${ }^{\mathrm{TM}}$ \\
\hline 5 & $\begin{array}{l}\text { Pressure equalization } \\
\text { chamber }\end{array}$ & 9 & & $\begin{array}{l}\text { at amendment } \\
\text { inlet }\end{array}$ & \\
\hline 6 & Air flow meters & & 10 & Air pump & \\
\hline
\end{tabular}


Czechowice Oil Refinery

Bioremediation Demonstration

Test Plan
WSRC-RP-97-214

Revision: 1

May 10, 1997

Figure 2. Individual column set up

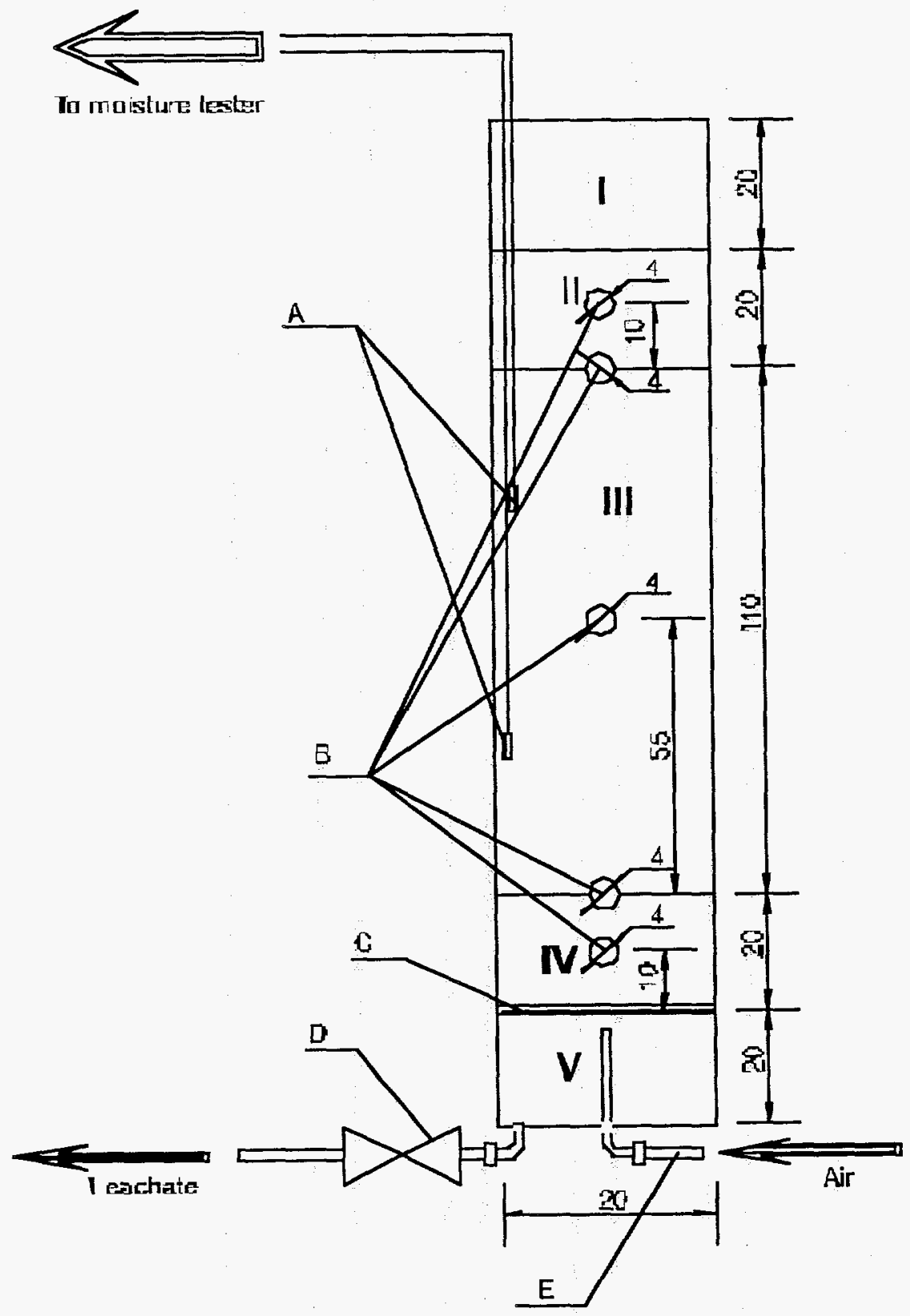

Figure legends

Section I Column head space ( $20 \mathrm{~cm}$ high)

Section II Topsoil layer $(20 \mathrm{~cm}$ thick)

Section III

Contaminated soil mixed with

$10 \% \mathrm{v} / \mathrm{v}$ woodchips $(110 \mathrm{~cm}$ thick $)$

Section IV Dolomite aggregate $(20 \mathrm{~cm}$ thick)

Section $\mathrm{V}$ Inlet housing
A Moisture blocks

B Sampling ports

C Porous base

D Leachate valve

E Air Inlet*

(active only) 
Czechowice Oil Refinery

Bioremediation Demonstration

Test Plan
WSRC-RP-97-214

Revision: 1

May 10, 1997 
Czechowice Oil Refinery

Bioremediation Demonstration

Test Plan

Appendix E

Sample and Monitoring Plan
WSRC-RP-97-214

Revision: 1

May 10, 1997

\section{i}


- Initial monitoring of biopile (passive and active areas), sample all quadrats for soil parameters, weekly samples of water and soil gas until soil sampling complete.

- Sample soil gas and water only during initial startup tests and respiration tests.

- Sample soil gas and water weekly, and soil from random quadrats monthly during operating campaigns

- Respiration tests at end of operating campaigns, ie. every 3 months or less.

- Sample soil in all quadrats at end of demonstration.

- Emphasis on schedule and documentation. 
Czechowice Oil Refinery

Bioremediation Demonstration

Test Plan

Appendix F

Mobilization Plan
WSRC-RP-97-214

Revision: 1

May 10, 1997 
- Remove Sludge from lagoon $A$ and sell to cement kiln as fuel - mixing and trial burns completed September 96.

- Dewater lagoon A - completed April 97

- Clean and prepare bottom of lagoon using natural clay bottom - completed May 8, 1997

- procure: Dolomite, fabricate leachate pipe (ceramic), valves and fittings for leachate pipe, sump, soaker hose, pipe for irrigation, flow meters and valves for air injection, fabricate 23 piezometers (short and long), baroballs, helium fittings/regulator, helium, wood chips, top soil, and grass seed

- install dolomite and leachate pipes

- mix contaminated soil with wood chips

- install contaminated soil

- install top soil and grass seed

- install air injection system and sweetwater pump

- install leachate recirculation including sump and wastewater treatment connections

- system tests 
Czechowice Oil Refinery

Bioremediation Demonstration

Test Plan

Appendix G

Start-Up and Operation Plan
WSRC-RP-97-214

Revision: 1

May 10, 1997

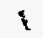


Czechowice Oil Refinery

Bioremediation Demonstration

Test Plan
WSRC-RP-97-214

Revision: 1

May 10, 1997

- Baseline testing (2-3 weeks)

- System Startup Step Tests with Respiration Tests (7 weeks Max.)

- First Operating Campaign (3 months)

- no nutrient amendments (dependent on initial tests)

- air injection continuous, flow regulated by temperature $40-50^{\circ} \mathrm{C}$

- Subsequent Operating Campaigns (3 months each)

- season differences

- nutrient amendments

- pulsed air injection

- higher and lower flow rates for air injection

- higher or lower leachate recirculation rates

56 
Czechowice Oil Refinery

Bioremediation Demonstration

Test Plan
WSRC-RP-97-214

Revision: 1

May 10, 1997

\section{Health and Safety Plan}


Czechowice Oil Refinery

Bioremediation Demonstration

Test Plan
WSRC-RP-97-214

Revision: 1

May 10, 1997

\author{
Joint International Technology Demonstration Project \\ Health \& Safety Plan \\ For \\ Czechowice Refinery Site Remediation
}

\title{
I. Project Overview
}

This Health and Safety Plan addresses the first phase of a multi-phase, joint project including the U.S. Department of Energy and the Institute for the Ecology of Industrial Areas in Katowice, Poland. This institute and this region of Poland offer unique opportunities for conducting environmental research, developing and demonstrating environmental remediation technologies and for implementing projects which result in bilateral benefits to the U.S. and Poland.

The specific goals of this project are to demonstrate the methodologies and technologies associated with site characterization, risk assessment and site remediation, using a site in Poland and to provide a mechanism for the transfer of those methodologies and technologies to Poland and other countries in the region. The project includes the following components:

- Expedited Site Characterization (ESC) - The goal of this component is to collect the information necessary to: identify the nature, extent and movement of subsurface contamination in order to assess the risks to site workers, nearby residents and the environment, and provide the necessary data for the design and implementation of a site remediation strategy.

- Risk Assessment - The risk posed to humans and the environment by site contamination will be evaluated using appropriate exposure scenarios. Site-specific, risk-based cleanup goals for the soils and groundwater at the site will be developed.

- Remediation - Based upon the results of site characterization and risk assessment, the appropriate remediation technology or technologies will be selected to address the contamination at the site.

\section{Site Overview}

\section{A. Site Selection}

The Czechowice Oil Refinery has been selected as the demonstration site for this project based on the suitability of the site for the planned demonstrations An important consideration in the selection process was finding a cooperating partner in Poland that would move quickly and decisively in providing site access and funding needed to complete site preparations necessary for the project.

The refinery is approximately 100 years old and uses the catalytic cracking process to refine crude oil. The waste stream from the refinery process (a thick, viscous semi-liquid) empties into a series of lagoons. The lagoons contain several million gallons of this heterogeneous and relatively uncharacterized waste product. It is expected that the immediate subsurface is heavily contaminated with hydrocarbons and the deeper subsurface also may be contaminated. The project will demonstrate technologies to characterize, assess and remediate one of these lagoons.

\section{B. Site History and Description}

The Czechowice Oil Refinery, started its operation in 1896, when the Schodnica refinery was built. In 1902 , in the vicinity of the Schodnica refinery; the construction of a larger and much more competitive modern refinery was started. This second refinery was built by Vacuum Oil Company, which was owned by Socony Vacuum Oil lncorporation, New York. 
Czechowice Oil Refinery

Bioremediation Demonstration

Test Plan
WSRC-RP-97-214

Revision: 1

May 10, 1997

The first refinery processed 35000 tons of paraffinic crude oil a year. In 1931, the first Foster Wheeler distillation unit in Poland was built at the refinery. The refinery was bombed in August, 1943 by the Allies and only partly rebuilt by the Germans during the war. The restoration was finished by Polish engineers and workers shortly after the end of the World War II. Production resumed in February 1946.

An additional plant was built on the site in 1954 to refine cresol. The original plant was rebuilt with an increased capacity of 25000 tons a year. The capacity of the new part of the refinery was increased in the period of 1959 and 1962 to a capacity of 500000 tons a year. A fire damaged part of the refinery in 1971 but it was rebuilt quickly. In 1985, thallic and turpentine oil processing plants from a separate company were incorporated into the refinery. The refinery is currently being denationalized.

Petroleum is the main raw material and is used to produce the following products: ethyl gasoline, engine oil, fuel oil, paraffins and paraffin products, asphalts, engine and special oil, oil products. The byproducts of these processes, an oil-water sludge, is disposed in three lagoons which cover an area of approximately 3,8 ha to a depth of approximately $3 \mathrm{~m}$. The three lagoons contain a total of approximately 121.4 thousand tons of sludge, rubble and dirt. One of these three lagoons is to be the site of this demonstration.

\section{Site Geography and Local Land Use}

The refinery is located in the eastern part of the town of Czechowice-Dziedzice. Czechowice-Dziedzice is situated in the south-west of Poland, in the southern part of the Katowice province $-45 \mathrm{~km}$ from the city of Katowice, $8 \mathrm{~km}$ from the town of Bielsko-Biala and about $6 \mathrm{~km}$ from Goczalkowice Lake. Czechowice-Dziedzice covered the area of $33 \mathrm{~km}^{2}$ and is inhabited by 35615 people; the population density is 1079 people $/ \mathrm{km}^{2}$.

\section{SCOPE OF WORK}

This HASP covers only the activities related to the remediation part of the project.

For a complete list of activities see Test Plan ( WSRC rev 1 ).

\section{A. Planned Site Activities}

- Mobilization : $5 / 97-6 / 97$

Base line studies

Site construction

- Operation : 6/97-6/98

System testing

Determination of operational parameters

- Monitoring : 5/97 - 6/98

\section{B. Number of People On site}

IETU - up to 5 persons

Refinery - up to 5 persons

WSRC - up to 3 persons

Note: These are maximum numbers and that not all of these persons are expected at one time. Actual maximum numbers at any one time are expected to range from 5-8 persons. 
Czechowice Oil Refinery

Bioremediation Demonstration

Test Plan
WSRC-RP-97-214

Revision: 1

May 10, 1997

C. Number of Days to Complete Work Approximately 365 calendar days.

\section{WASTE CHARACTERISTICS}

\section{A. Waste Type(s)}

Liquid

Gas

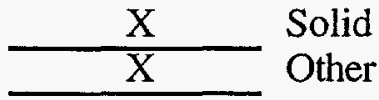

B. Waste Characteristics

Corrosive

Ignitable

Unknown

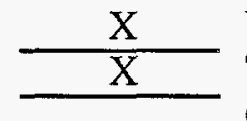

Volatile

Toxic

Other (Name)
$\mathrm{X}$

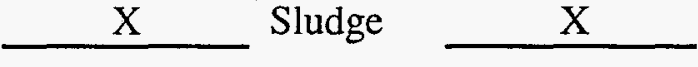

\section{HAZARD EVALUATION}

\section{A. Chemical Hazards}

Polynuclear aromatic hydrocarbons (PAHs) are known to be associated with refinery sites. Other typical refinery wastes include: oils which contain light aromatics (i.e., benzene, toluene, and xylenes). The following are regulatory standards and advisory levels for the potential chemical constituents at the refinery site.

\section{REGULATORY STANDARDS AND ADVISORY LEVELS FOR PAH COMPOUNDS IN AIR}

\begin{tabular}{|c|c|c|c|c|c|}
\hline \multirow[t]{2}{*}{ Compound } & \multirow[t]{2}{*}{ Agency } & \multicolumn{2}{|c|}{ Regulatory Standard $\left(\mathrm{mg} / \mathrm{m}^{3}\right)$} & \multicolumn{2}{|c|}{ Advisory Level $\left(\mathrm{mg} / \mathrm{m}^{3}\right)$} \\
\hline & & 24 hour & 30 minute & 8 hour & 30 minute \\
\hline Benzene & MEP & 10 & & & \\
\hline & MWSP & & & 10 & 40 \\
\hline Toluene & MEP & 200 & 300 & & \\
\hline & MWSP & & & 100 & 350 \\
\hline Xylene & MEP & 100 & 300 & 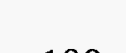 & \\
\hline Ethyl benzene & $\begin{array}{l}\text { MWSP } \\
\text { NIOSH }\end{array}$ & & & 100 & 350 \\
\hline & MWSP & & & 100 & 500 \\
\hline Naphthalene & NIOSH & & & & $\sigma$ \\
\hline & MWSP & & & 20 & 75 \\
\hline
\end{tabular}

Abbreviations:

MEP - Ministry for Environmental Protection (Poland)

MWSP - Ministry for Welfare and Social Policy (Poland)

NIOSH - National Institute of Occupational Health and Safety (USA)

B. Physical Hazards 
Czechowice Oil Refinery

Bioremediation Demonstration

Test Plan
WSRC-RP-97-214

Revision: 1

May 10, 1997

Slips, trips, and falls. Site is active as an operations facility, so trucks and other vehicles will be operating on site.

\section{Hazards Posed by Site Activities}

Utilities and electrical lines (buried and above ground) are present on site.

D. Unusual Hazards

Due to the age and history of the site, many types of unknown materials may be encountered in and around the lagoons. Such materials could possibly include metallic debris, buried cables, wires or pipes. Use of the magnetic locator and GPR are is expected to reduce the possibilities of such encounters.

\section{E. Overall Hazard Level}

Low: During ground water sampling, hydrogeologic measuring and testing, and surveying low concentrations of contaminants are expected.

Moderate: During soil mixing construction, and source sampling, the potential of exposure to contaminants by inhalation or direct skin contact exists. Mechanical failure or errors from heavy equipment operations

also present a potential threat.

\section{PROCEDURES}

Abbreviations:

TWA - Time-Weighted Average

COR - Czechowice Oil Refinery

FTL - Field Team Leader

SSO - Site Safety Officer

\section{A. Training Requirements}

All personnel who will be engaged in hazardous waste operations must have completed, within the 12 months prior to the beginning of site activities, a hazardous waste site investigation training course or eight hour refresher course. The training must comparable to that described in OSHA regulations 29 CRIFR 1910.120 et seq.

\section{B. Level of Protection}
A
B
$\mathrm{C}$
$\mathrm{D} \quad \mathrm{X}$
Level D - Construction / Mobilization
Tyvek® coveralls or appropriate chemical-resistant suit
Outer gloves - Nitrile rubber or Neoprene
Inner gloves - Disposable Latex
Boots - Steel toe and shank, impermeable and chemical-protective Outer boot covers - Disposable rubber, impermeable and chemical protective
Hard hat (to be worn during drilling operations and when overhead hazards exist)
Safety glasses or goggles.
In other cases for monitoring and operation - street clothes and gloves. 
Czechowice Oil Refinery

Bioremediation Demonstration

Test Plan
WSRC-RP-97-214

Revision: 1

May 10, 1997

Please refer to IETU Risk Assessment Report 1997.

\section{Action Levels}

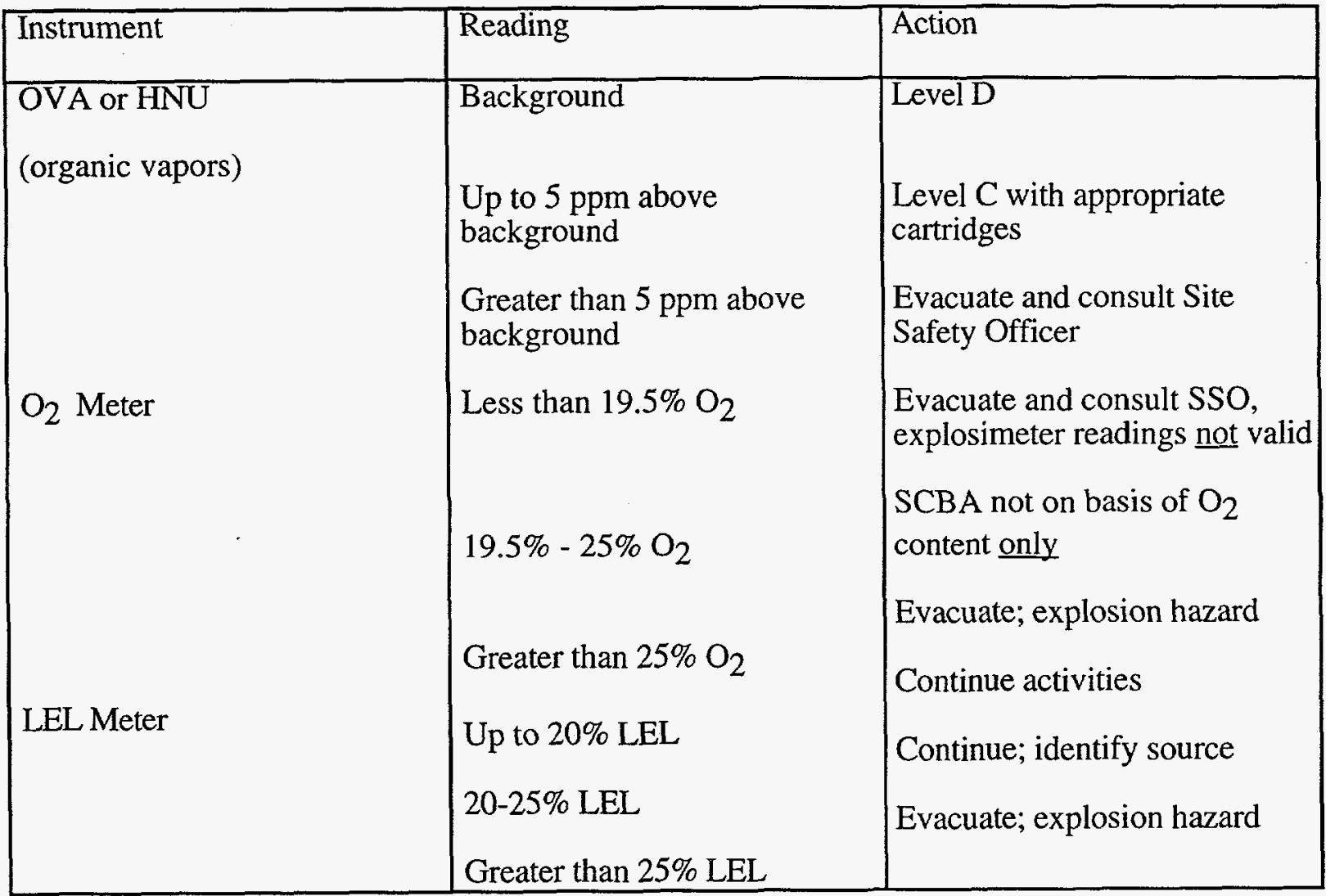

\section{Monitoring Requirements}

Ambient air monitoring will be conducted continuously while site activities are in progress. Monitoring instruments will include the following:

- H-NU (PID) for organic vapors.

$-\mathrm{O}_{2}$ /LEL meter

- Dust meter (as required)

The SSO will record instrument readings every 60 minutes or when significant changes occur. Upgrade/downgrade decisions will be based on monitoring results in the breathing zone and the action levels listed above. Calibration and maintenance of monitoring equipment will be the responsibility of the SSO and will be conducted in accordance with manufacturer's requirements as listed in the appropriate manual.

\section{E. Site Organization and Control}

Map/Sketch Attached? yes

Perimeter Identified? yes 
Czechowice Oil Refinery

WSRC-RP-97-214

Bioremediation Demonstration

Revision: 1

Test Plan

May 10, 1997

Zone(s) of Contamination Identified? No

Note: Work areas within the site (exclusion area = contamination reduction area, support area) should be established so that the support area is upwind of the exclusion area. One or more flags should be placed on site to determine wind direction.

Figure 1 depicts the location of the Czechowice Oil Refinery site and the nearest available hospital. Figure 2 shows the layout of the site itself.

Screen for hazards during mobilization and at the beginning of each operating campaign and adjust PPE accordingly.

F. Initial Procedures

- Locate nearest available telephone

- Confirm and post emergency telephone numbers and route to hospital

- Designate one vehicle for emergency use

- Perform initial site reconnaissance.

- Hold safety briefing for all participants before work begins

G. Work Limitations

- No eating, drinking, chewing of gum or tobacco, or smoking in the exclusion and contamination reduction zones.

- No contact lenses to be worn in the exclusion and contamination reduction zones.

- Work restricted to daylight hours only

- Buddy system to be used at all times in exclusion zone.

- Work to stop during thunderstorms or electrical storms

- No facial hair that would interfere with respirator fit.

H. Decontamination Procedures

Decontamination Procedures are not provided for the Site Remediation.

\section{Disposal Procedures}

Used Protective Clothing and Miscellaneous Wastes: Used protective clothing and other miscellaneous wastes will be bagged and disposed of through routine waste disposal procedures at the Czechowice Oil Refinery.

\section{J. Safety Equipment}

- Fire extinguishers

- Eye-wash bottles

- First aid kit

\section{EMERGENCY INFORMATION}

\section{A. Emergency Routes}

(Figure 3. Emergency Response Plan)

\section{B. Contingency Plan}


Czechowice Oil Refinery

Bioremediation Demonstration

Test Plan
WSRC-RP-97-214

Revision: 1

May 10, 1997

\section{General Information}

The Field Team Leader or SSO will contact the local hospital emergency room, police department, fire department, ambulance, and other emergency services before field activities begin. The Field Team Leader or SSO will inform the hospital emergency room and ambulance service of probable emergencies and provide necessary information to the hospital prior to the start of the investigation. This will assist local personnel in being prepared should an emergency arise during investigation.

The SSO will be responsible for establishing, then adjusting as necessary, appropriate levels of eye, skin, and respiratory protection for the investigation. The SSO will ensure that all participants conduct their work in accordance with the Site Safety Plan and applicable safety rules and will direct any assigned employee to leave the site if he or she fails to observe safety requirements or in any way creates a safety hazard.

At ambient temperatures of $7^{\circ} \mathrm{C}$ or below, hourly warm-up breaks will be taken, and cold stress monitoring will be implemented. Warm beverages may be given. At ambient temperatures of $27^{\circ} \mathrm{C}$ or above, hourly breaks will be taken, and heat stress monitoring will be implemented. Cold beverages may be given to replenish fluids. In either event, work schedule adjustments may be required.

All employees will be directed to bring to the attention of the Field Team Leader and SSO any unsafe condition, practice, or circumstance associated with or resulting from the investigation.

In cases of immediate hazard to employees or the public, employees on the scene will take all practical steps to eliminate, neutralize, or avoid the hazard. This may include leaving the site. The Field Team Leader will take the steps necessary to ensure that the investigation is completed safely. These steps may include changes in field procedures, removal or neutralization of a hazard, consultation with appropriate experts, or use of specialists. All such actions will be coordinated with and approved by the Site Safety Officer.

\section{Site Safety Briefings}

Before the investigation begins, the SSO will hold a site briefing. All members of the investigation team, including contractors, will attend this meeting. During this meeting, the SSO will discuss safety equipment use, maintenance, and limitations; accident reporting procedures: and decontamination procedures. Questions about the project will be answered, and the Site Safety Plan Certification will be signed by all team members during the initial briefing. The SSO will also hold a similar meeting with individuals who later become a part of the investigation team before they take part in investigation activities. Subsequent periodic briefings will be held throughout the course of the investigation, especially when unsafe practices are noted or a change in site conditions requires modification of the Site Safety Plan.

\section{Visitors}

Occasionally a situation will arise in which someone visits a site during site activities. In general, most visitors will be accommodated by being permitted to observe activities from the Support Zone. Visitors who present to the SSO certification of completion of a hazardous waste site investigation training course or refresher course (in the last 12 months) in compliance with OSHA regulations found at 29 CFR 1910.120 et seq. will generally be granted access, provided that they are dressed in suitable protective equipment, they assume all responsibility, and the owners do not object. Visitors without the training course who desire access to the Exclusion Zone must obtain permission from the owners and the SSO. All visitors, who enter the Exclusion Zone and/or Contamination Reduction Zone will be advised of the nature and level of exposure likely as a result of project-related activities and that they and their employees must assume all risk. Copies of this Site Safety Plan will be provided to these personnel for informational purposes only. 
Czechowice Oil Refinery

Bioremediation Demonstration

Test Plan
WSRC-RP-97-214

Revision: 1

May 10, 1997

\section{Accident Response Procedures}

\section{General Procedures}

In the event that any member of the party experiences any adverse effects or symptoms of exposure during an investigation activity, the individuals involved with the particular investigation activity will leave the Exclusion Area and seek appropriate medical aid for the affected individual. The SSO will be in charge of health and safety measures. If he or she is not present or injured, the Field Team Leader will be in charge. In the event that any member of the party is overcome, incapacitated, or traumatically injured while on site, the remaining members will immediately done appropriate protective equipment and make reasonable efforts to rescue the affected person. Once removed from the area where the incident occurred, the affected person will not be left unattended, and medical assistance will be summoned. If it is necessary to drive the victim to the hospital, two field personnel will accompany the victim. One other person from the field crew will be designated by the SSO to call ahead to the emergency room and provide information about the accident before the victim arrives. If the SSO is injured, the Field Team Leader will designate a person to call ahead to the hospital. If possible, limited decontamination will be conducted, but not if time is critical to get the injured person to medical aid. If it is determined that the problem was due to chemical exposure, all members of the party exposed to those chemicals will proceed expeditiously, in a group, to the hospital. In those cases where personal contamination has occurred, all persons involved will make every reasonable effort to decontaminate themselves to minimize spreading of contaminants.

\section{Procedures for Emergencies Posing an Immediate Threat to Life. Limb. or Health of One or More Persons in the Exclusion Area.}

Examples: explosion, excessive smoke, fire, excessive concentrations of organic contaminants, equipment accident, person unconscious, nausea, dizziness, safety or protective equipment malfunction.

(1) Any person involved in or witnessing an accident or other threatening situation will notify the other personnel immediately.

(2) Injured persons, partners or other personnel close to them will lend assistance. Personnel will not unduly jeopardize their own lives to assist an injured person, The injured person will be moved only when necessary to avoid further hazards.

(3) All activity in the Exclusion Area will cease and personnel not involved in providing assistance to the injured or endangered personnel will depart to the Support Area.

(4) The SSO will immediately call the proper authorities (ambulance, fire, police, rescue teams, etc.). If the SSO is injured or absent, the Field Team Leader will call the proper authorities.

(5) Personnel will not reenter the Exclusion Area until allowed by the SSO or Field Team Leader. The SSO or Field Team Leader will assess the nature of the emergency and correct the matter before allowing re-entry.

(6) A complete written report of the incident will be made by the injured personnel and the SSO or Field Team Leader and sent to the AL/TIP Site Safety Coordinator.

3. Procedures for Minor Accidents in the Exclusion Area.

Examples: sprains, small cuts or scrapes, equipment malfunction.

(1) The person injured will cease work, notify his/her partner, and exit with the partner to the Support Area and obtain adequate medical attention or equipment repair.

4. Procedures for Emergencies Posing an Immediate Threat to Life, Limb, or Health of One or More Persons in the Contamination Reduction or Support Area.

(1) Persons at the scene will lend assistance and perform the necessary first aid, CPR, etc.

(2) The SSO will immediately call the proper authorities (ambulance, fire, police, poison control center, rescue teams, etc.). If the SSO is injured or absent, the Field Team Leader will call the proper authorities. 